\title{
Seismic risk reduction in Croatia: mitigating the challenges and grasping the opportunities
}

Marta Šavor Novak

Josip Atalić

Mario Uroš

Snježan Prevolnik

Miroslav Nastev

Marta Šavor Novak, Josip Atalić, Mario Uroš

University of Zagreb, Faculty of Civil Engineering,

Department of Engineering Mechanics, Croatia

Snježan Prevolnik

University of Zagreb, Faculty of Science, Department of Geophysics,

Croatia

Miroslav Nastev

Natural Resources Canada, Geological Survey Canada, Quebec City,

$P Q$, Canada

Corresponding author: Marta Šavor Novak, msavor@grad.hr

https://doi.org/10.5592/CO/FTCE.2019.04 


\section{Seismic risk reduction in Croatia: mitigating the challenges and grasping the opportunities}

\section{Abstract}

Croatia is located in a seismically active region of Southern Europe. Disastrous earthquakes have occurred in the past and can hit again and, if not adequately addressed, losses to life and property can be significant. Yet, there is still not enough community awareness and understanding of the potential seismic risk, although it is indispensable for successful mitigation strategies. This paper discusses the current state of knowledge and practice related to seismic risk assessment and reduction activities in the country, and gives suggestions on how to effectively overcome challenges and seize the opportunities to increase community resilience.

Key words: seismic risk assessment, seismic hazard, building stock, vulnerability assessment, risk reduction related activities

\section{Izazovi i mogućnosti smanjenja rizika od potresa u Hrvatskoj}

\section{Sažetak}

Hrvatska se nalazi u seizmički aktivnoj regiji južne Europe. U prošlosti su se na tom području događali katastrofalni potresi pa ako se ne poduzmu odgovarajuće mjere, novi potresi mogu dovesti do značajnih gubitaka ljudskih života i imovine. Međutim, još uvijek nema dovoljno svijesti i razumijevanja zajednice o mogućem seizmičkom riziku, ključnih za uspješne strategije ublažavanja posljedica. $U$ radu se prikazuje sadašnje stanje znanja i prakse o procjeni seizmičkog rizika i aktivnostima njegovog smanjenja u Hrvatskoj, te se daju prijedlozi kako učinkovito prevladati izazove i iskoristiti mogućnosti za povećanje sposobnosti oporavka zajednice.

Ključne riječi: procjena seizmičkog rizika, seizmički hazard, fond građevina, procjena oštetljivosti, aktivnosti ublažavanja rizika 


\section{Introduction}

Located in Southern Europe, Croatia belongs to the Mediterranean-trans-Asiatic highseismic activity zone making it one of the most earthquake-prone countries in Europe (Figure I). It can be observed that the regions the most exposed to earthquakes include the coastal area and the north-western part, characterized with bedrock peak ground acceleration (PGA) of more than $0.25 \mathrm{~g}$ at probability of exceedance of $10 \%$ in 50 years (return period of $I$ in 475 years).

These earthquake prone regions spread over approximately $30 \%$ of Croatia and are characterized by a relatively dense population and large urban centres. Of particular economic and social importance are the urban areas of Zagreb, Split, Dubrovnik and Rijeka with about $60 \%$ of the country's population. Zagreb itself, as the administrative, cultural, scientific, economic, and traffic centre of the country, accounts for almost 20 $\%$ of the population and about one third of the country's GDP [I].

Strong earthquakes have occurred in Croatia in the past and will occur again. If not adequately addressed, the loss of life and property from this natural hazard can be enormous.
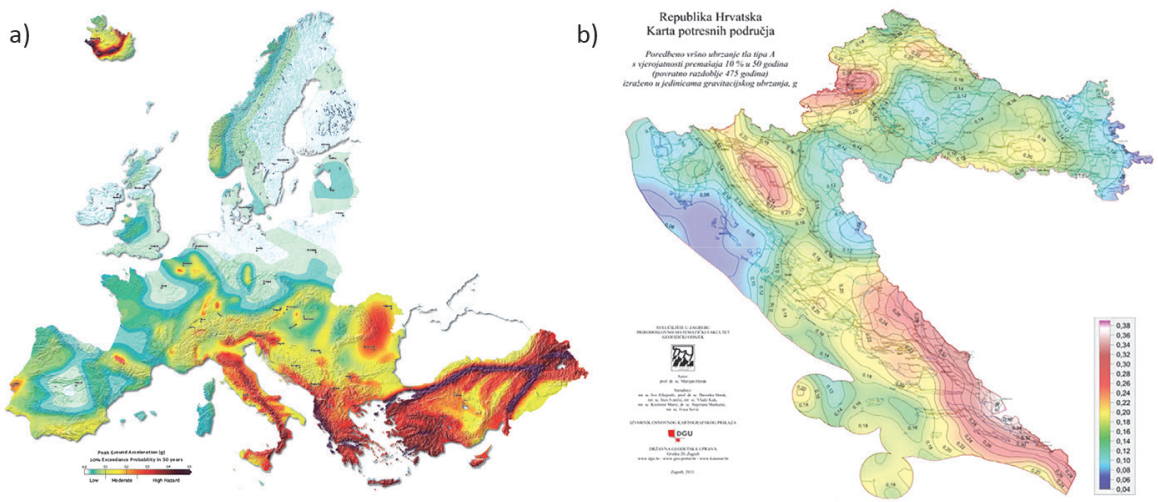

Figure I. Expected peak ground acceleration (PGA) on bedrock with probability of exceedance of $10 \%$ in $\mathbf{5 0}$ years (return period of I in $\mathbf{4 7 5}$ years) for: a) Europe [2], and b) Croatia [3]

\section{Historic earthquakes in Croatia}

The largest recorded earthquake in Croatia was the 1667 MCS intensity X earthquake that struck Dubrovnik and neighbouring regions [4]. It was reported that the seismic shaking was followed by a tsunami, that a fire broke out in the old city and that some 3,000 people lost their lives, while most of the buildings collapsed (Figure 2a). Zagreb and its surroundings also experienced strong earthquakes over the past few centuries. During the $1880 M_{L} 6.3$ Great Zagreb Earthquake, with the epicentre in the nearby 
Medvednica mountain, practically all buildings were affected to a certain degree, with about $13 \%$ heavily damaged and collapsed buildings, Figure 2c-e [6]. This resulted in immediate heavy depopulation of the city, which took local authorities more than 25 years to reconstruct. Among the more recent earthquakes in Croatia, the most notable one is the $1996 M_{L}=6.0$ Ston earthquake followed by hundreds of aftershocks [8]. The old town and its surroundings were heavily damaged. In total, approximately I,900 buildings, I 245 of which were residential, suffered damage in the area of 400 $\mathrm{km}^{2}$ (Figure 2f-h). The Ston earthquake warned of the insufficient capacity of the Croatian disaster relief and response system in case of large disasters. In particular, concerns were expressed regarding the post-earthquake damage assessment and long-term recovery process [9].
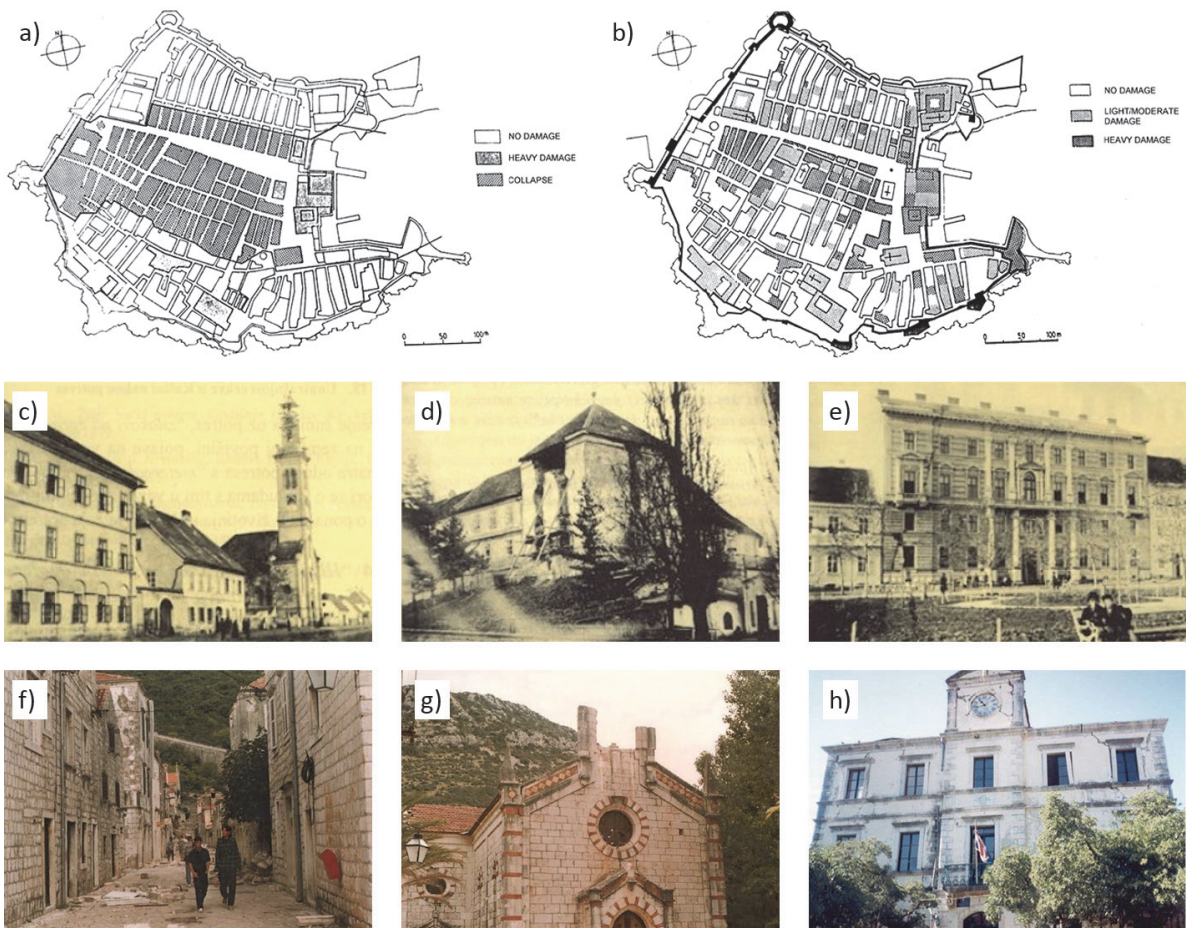

Figure 2. Damage observed in Croatian cities following strong earthquakes. Dubrovnik: a) 1667 MCS X Dubrovnik earthquake and b) 1979 M7.2 Montenegro earthquake [4]; Zagreb, 1880 Great Zagreb $M_{L} 6.3$ earthquake: c) Vlaška street, d) Upper Town, Popov tower - observatory e) Zrinjevac, Archaeological museum [6]; and Ston, $1996 M_{L} 6.0$ Ston earthquake: f) through $h$ ) [7] 


\section{Historic earthquakes in the region}

For a long time, the seismic risk assessment at urban scale was a kind of natural science, where the prediction of potential seismic impacts was based on comparisons to observed damage and losses from strong earthquakes in the neighbouring countries with similar seismic settings, e.g., seismic hazard, construction practices, etc. Although sophisticated seismic risk assessment tools that can rapidly compute potential negative effects have become available over the last decades, this empirical approach has still remained very attractive, mainly due to its simplicity. Since 2009, Italy has gravely suffered from a series of earthquakes, some of the most striking ones being the 2009 M6.3 Aquila, 20I2 M6.I Emilia Romagna, and 2016 M6.2 Central Italy. These earthquakes have greatly affected the population, economy, environment, and the society as a whole (Figure 3a-c).
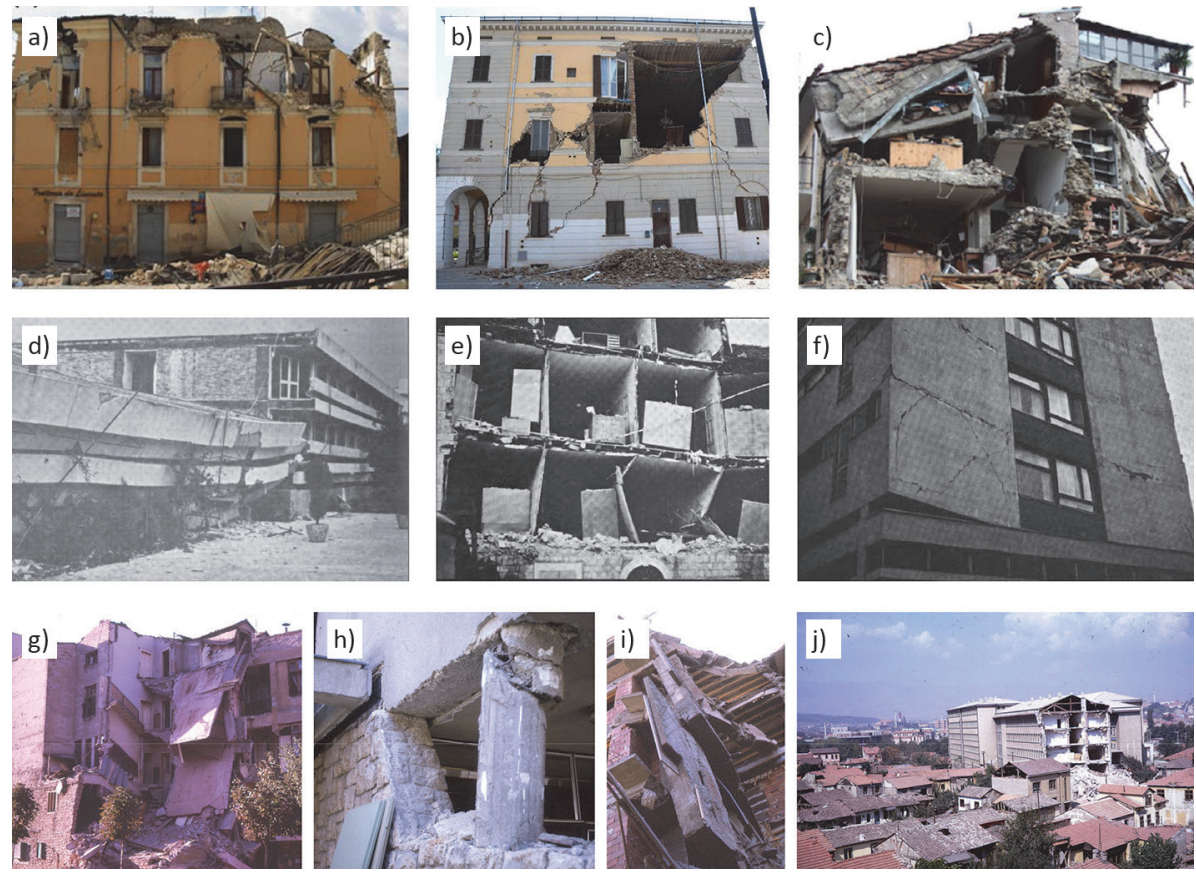

Figure 3. Disastrous earthquake activity in the region. Italy: a) 2009 M6.3 L'Aquila: Apartment building from the late nineteenth century [I0], b) $2012 \mathrm{M6} . \mathrm{I}$ Emilia Romagna: heavily damaged city hall of Sant'Agostino [II], c) 2016 M6.2 Amatrice: building collapse [13]; 1979 M6.9 Montenegro: d) Hotel Slavija pancake collapse, e) total exterior wall collapse at an old stone house in Kumbor, $f$ ) diagonal shear cracks in infilled walls of Hotel Tamaris [15]; and 1963 M6.I Skopje: g) apartment building collapse, h) short column failure at the university student refectory, i) collapse of a brick wall structure with concrete floors, j) collapse of exterior wall of an apartment building [17] 
Older historic buildings of inestimable heritage value were especially affected [10][13]. For example, the province of Emilia Romagna, for which a considerably lower seismic hazard is predicted compared to Zagreb, suffered 27 fatalities and heavy damage to I,200 residential and 600 industrial buildings in two consecutive M5.7 and M5.8 earthquakes. The total economic loss was estimated at $€ 12$ billion [14].

Not so long ago, in 1979, a disastrous M6.9 earthquake occurred in Montenegro (Figure 3d-f), and its consequences were felt in the wider region of former Yugoslavia. Some I 30 people lost life, more than I,000 were injured requiring hospitalization, and about 80,000 were left homeless. Estimated losses amounted to US\$ 2.7-3.5 billion and, in some places, more than $80 \%$ of the building stock was destroyed or damaged beyond repair [15].

Although located more than $80 \mathrm{~km}$ to the north-west of the epicentre, many buildings in Dubrovnik were also affected (Figure 2b), including I,07I historic monuments, e.g., Rector's Palace, Dubrovnik Cathedral, St. John Fortress, etc. Therefore, a vast post-earthquake damage assessment project was conducted followed by a multi-year reconstruction effort [4]. One of the most damaging earthquakes in the region was the 1963 M6.I Skopje earthquake causing I,063 fatalities and between 3,000 and 4,000 injuries. More than $40 \%$ of dwellings were destroyed or significantly damaged with an estimated economic loss equalling $15 \%$ of the former Yugoslavia's GDP (Figure 3g-j) [16].

\section{Practices and policies}

Similarly to any other region worldwide, South-Eastern Europe, including Croatia, has certain regional similarities and particularities with regard to construction practices. They can have a major impact on the behaviour of buildings and other man-made structures subjected to dynamic earthquake loading. In this respect, the historical legacy of a significant part of the building stock derived from former Yugoslavia and built according to the same concept and codes has to be accounted for.Accordingly, numerous types of buildings that were significantly damaged or collapsed during the 1963 Skopje earthquake still make up much of the present building stock in Croatia. It is estimated that about a third of all residential units in Croatia were built before any seismic building codes were put in place.

It is a well-known fact that the main cause of fatalities during devastating earthquakes is either partial or total collapse of buildings [18]. Particularly critical are failures of unreinforced masonry buildings that are common in Croatia, making a large percentage of the existing building stock. Statistical data also point to an increasing number of fatalities in reinforced concrete (RC) structures, with concrete becoming the preferred material for buildings. Collapse of concrete structures can often have more ominous consequences compared to masonry structures [19], as a result of inadequate construction details and low ductility of structural elements.

Following the 1963 Skopje earthquake, there was a swift rise of awareness among scientists, technical experts and the general public in former Yugoslavia about the potential threat and consequences of earthquakes [20]. Devastating earthquakes 
that followed in the 1960s and 1970s prompted the federal government to adopt a new generation of seismic codes for construction in seismically active regions [2I], [22]. In addition, significant financial resources were invested in research devoted to abatement of seismic risk. This refers particularly to seismic hazard studies, analyses of seismic vulnerability of buildings, and enhancement of the earthquake resistant design and construction practices in the scope of national and international projects, such as the UNDP/UNESCO/RER/79/0 I 4 Seismic risk reduction in the Balkan Region and the UNDP/UNIDO project RER/79/0I5 Building construction under seismic conditions in the Balkan Region, implemented in the 1980s [23].

\section{Rationale}

Considering the post-1995 period, it seems that the opportunity for increasing seismic awareness among decision makers has not been seized, nor has sufficient emphasis been given to the seismic risk reduction. Likewise, more than 25 years since the Ston earthquake, the question of disaster preparedness and response, capabilities and capacities in the case of a strong earthquake in most of the urban areas, is still highly topical.With the ongoing steady population decline due to the negative natural growth rate and emigration, a strong earthquake would most probably aggravate the depopulation problem in Croatia. Although Croatia ranks among countries with a relatively high-income [24], it can be assumed that a major disaster could not efficiently be managed by its economy, and it seems that capacities in Croatia for fast post-earthquake reaction (search and rescue, damage assessment, etc.) are still limited. Thus, despite the relatively high seismic risk (a statement which will be confirmed in the next sections) and regular media reports on earthquakes felt across Croatia, the disaster resilience (defined as ability of a structure, system, network or region to return to a level of normalcy within reasonable time following the occurrence of an event) is relatively low.

The above issues are becoming critical in an effort to increase awareness among Croatian decision makers and local communities of their own seismic risk, and of the importance of applying systematic risk reduction measures. The question that arises under such conditions is whether another devastating earthquake is needed to trigger systematic preparation and updating of existing seismic mitigation and response plans. Certainly not, the public safety community should not remain idle in the expectation of strong earthquakes. Certain proactive and cost effective measures can be applied right away and should gradually become mandatory, such as: seismic evaluation of schools, hospitals and other essential facilities; seismic retrofit of the existing vulnerable buildings; development of customized disaster preparedness plans, etc. Obviously, all these mitigation, preparedness, and emergency response measures need to be tailored to potential impacts and consequences, e.g., structural damage, disruption of economic activity, social losses, etc., and also to the capacity of adaptation of Croatian communities. This is where the role of risk assessment becomes fundamental in providing each community and the society as a whole with the information needed for an informed decision-making. The seismic risk 
assessment is a process of measuring negative impacts of earthquakes and likelihood of their occurrence. It involves identification and quantification of three interrelated components: seismic hazard, inventory of assets at risk (exposure), and respective vulnerabilities (Section 2).

A detailed review of the current state of knowledge and practice related to the seismic risk assessment process in Croatia is presented in this paper. The most important seismic risk assessment studies are discussed in Section 3. Disaster risk reduction measures undertaken in the country are presented in Section 4. Potential ways forward for enhancement of the country's resilience to earthquakes are proposed in the final section.

\section{Seismic risk assessment process}

The seismic risk assessment is the prerequisite and key aspect in the implementation of successful mitigation strategies. It involves identification and quantification of three interrelated input components:

- seismic hazard,

- inventory of assets at risk (exposure), and

- respective physical vulnerabilities.

It is a process of measuring a variety of negative impacts generated by earthquakes and their likelihood. Traditionally, it is determined in terms of expected physical damage and economic and social losses as a consequence of future disastrous earthquakes. The calculations of potential impacts to human lives and economic losses are linked to the actual damage to exposed buildings and other structures [25]. Potential economic losses are probably the most difficult to evaluate. They can be divided into two categories: (i) direct losses refer to the repair and replacement of damaged structures and their contents, including the cost of debris removal, and (ii) indirect losses such as business interruption, disruption of industrial processes, extended transport time and costs, costs related to accommodation of displaced households, ensuing ripple effects to the economy, etc. In any case, detailed field surveys and data collection efforts are necessary for accurate assessment of seismic vulnerability and expected negative impacts. From an engineering point of view, the risk assessment is more focused on the evaluation of physical damage and the related direct economic losses. Indirect loss estimates require detailed analysis of complex economic parameters and are rather weak predictors of actual field conditions.

\subsection{Earthquake hazard}

Croatia belongs to the Mediterranean-trans-Asiatic high-seismic activity zone. This seismotectonic region is shaped by thrusting the Adriatic microplate (Adria) under the European lithosphere in the convergent boundary zone between the African and the Eurasian plates [26]. Dominant geotectonic features in Croatia are the Pannonian 
Basin, the Eastern Alps, the Dinarides, the Dinarides-Adriatic Platform transition zone, and the Adriatic Platform itself.The seismicity is unevenly distributed across the territory with most of the earthquakes occurring in the coastal area [4], whereas the seismicity of the central part of the continental area is much less pronounced. The Croatian earthquake catalogue (CEC) is maintained and updated on a yearly basis by the Department of Geophysics, University of Zagreb [27]. Figure 4 shows epicentres of recorded earthquakes for the period between 373 BC and 20I5 AD [28].

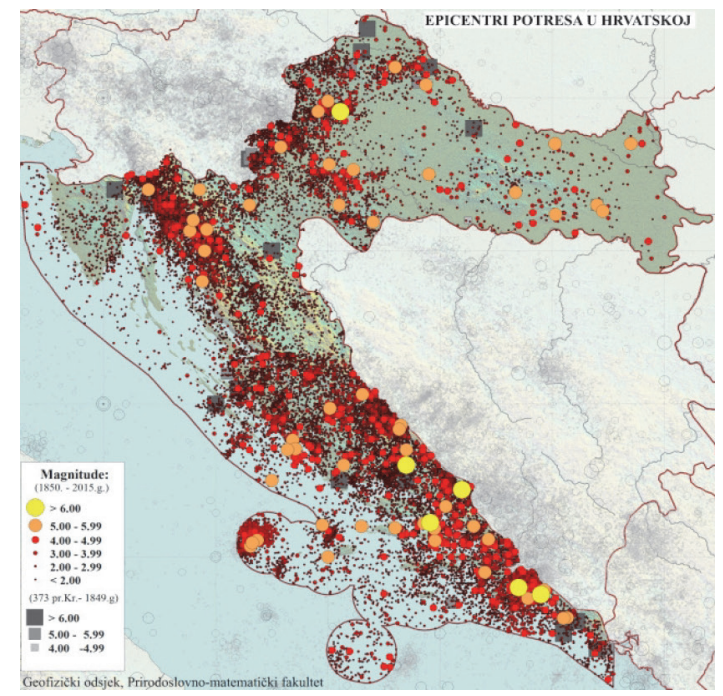

Figure 4. Epicentres of recorded earthquakes in Croatia from $373 \mathrm{BC}$ to $2015 \mathrm{AD}$ [28]

The seismicity in the period from 2006 to 2015 reveals a total of 36,733 earthquakes recorded in Croatia and surrounding areas [26]. From these, 37 strongest main shocks with magnitudes $M_{L}$ ranging from 4.0 to 4.9 were relatively shallow upper crustal earthquakes of up to $20 \mathrm{~km}$ in depth. The extent and types of fault-planes that generated $3 \mathrm{I}$ of these earthquakes are shown in Figure $5 \mathrm{a}$. On the other hand, Figure $5 b$ depicts magnitude-frequency correlation for 10,663 main events with $M_{L} \geq 0.5$. The magnitude completeness threshold was estimated at about $M_{L}=1.9$.

The capital Zagreb has obviously the highest exposure and vulnerability to seismic risk. It is located in the north-western part of Croatia, i.e. in the border zone between the Alps, the Dinarides, and the Pannonian basin, and at the "triple junction" between the Periadriatic, Balaton and Drava transcurrent faults, which may generate moderate to strong earthquakes [29], [30]. In the existing and ongoing seismic risk assessments, the seismic hazard is defined according to the current seismic hazard map for Croatia compiled in 20II at the Department of Geophysics, Faculty of Science [3], [3I]. This map shows PGA values on bedrock according to EC8 with $10 \%$ probability of exceedance in 50 years and $10 \%$ probability of exceedance in 10 years (95 years 
return period). The entire coastal region, especially the Dubrovnik-Neretva County, with the peak ground acceleration values on bedrock exceeding $0.3 g$ for a return period of 475 years, and the north-western part of Croatia, have been defined as high seismicity areas. The example of the City of Zagreb will be discussed in the following sections due to the potentially high consequences for the city infrastructure, and for the overall national economy.
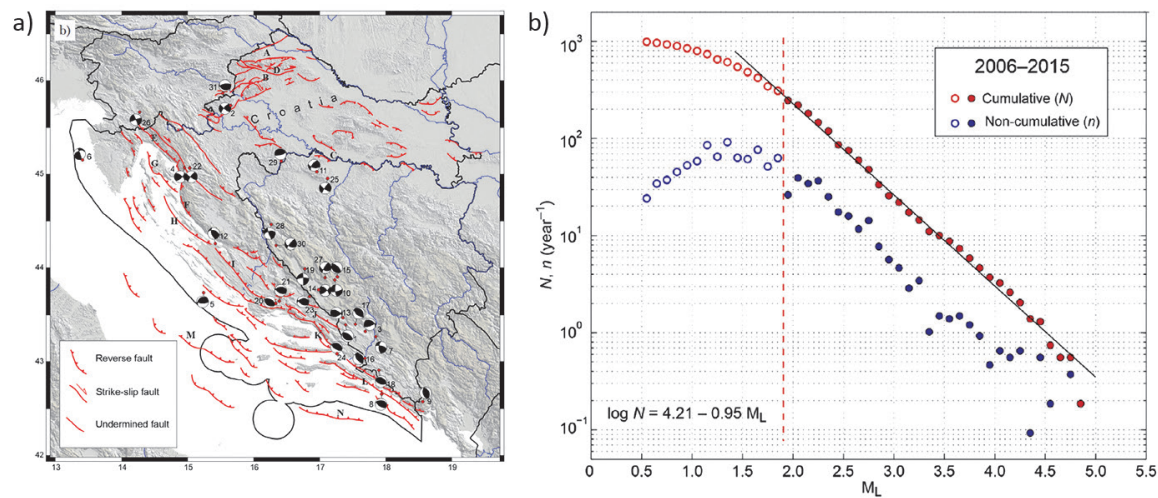

Figure 5. Earthquakes recorded in the period 2006-20I5 from the CEC database [26]: a) Fault-plane solutions for $3 I$ of the earthquakes with $M_{L} \geq 4$, and b) magnitude-frequency correlation for 10,663 main shocks with $M_{L} \geq 0.5$

A number of regional seismic hazard assessment and harmonization projects in Europe, and especially in the Euro-Mediterranean region, were implemented in the past, e.g., UNESCO/UNDP project Survey of the Seismicity of the Balkan Region realized in the seventies, Earthquake Risk Reduction in The Balkan Region (UNDP/UNESCO) implemented in the eighties [23], Global Seismic Hazard Assessment Project GSHAP implemented in the nineties (http://static.seismo.ethz.ch/GSHAP/), Harmonization of Seismic Hazard Maps in the Western Balkans, BSHAP(I-II), 2007-20I4 [32], and Seismic Hazard Harmonization in Europe (SHARE) project (http://www.share-eu.org/). The 2013 Euro-Mediterranean Seismic Hazard Model (ESHMI3), shown in Figure Ia, was generated within the SHARE project by applying probabilistic seismic hazard analyses (PSHA) for the region [I].This model is currently being updated through the Horizon 2020 SERA project (Seismology and Earthquake Engineering Research Infrastructure Alliance for Europe, http://www.sera-eu.org).

In general, seismic hazard maps are updated regularly thanks to additional earthquake records, improved knowledge and ongoing developments in the domain. They are implemented in seismic provisions of the building codes and provide up-to-date information to engineers on the potential shaking intensity levels throughout the country. The current Croatian seismic hazard map, dating back to 201 I (Figure Ib), was compiled based on approximately 40,000 earthquakes. In the meantime, the number of records in CEC has increased comprising more than I I 5,000 earthquakes. 
This fact alone imposes the need for deriving a new and updated seismic hazard map, which will certainly improve the accuracy of risk assessments. To this end, activities related to the re-interpretation of the Croatian seismological database and re-evaluation of the seismic hazard based on new seismological and seismotectonic information would need to be undertaken as soon as possible. This should include an update of seismogenic faults database compatible to the European database, selection of representative ground motion attenuation relation(s) for Croatia, development of a new seismicity model, and assessment of spectral accelerations for a number of periods and return periods. In parallel, geophysical and geotechnical measurements should be performed in the scope of future seismic microzonation studies for a more accurate identification of potential amplification due to local soil conditions, thus enabling determination of seismic hazard on the ground surface.

\subsection{Inventory of assets at risk}

The creation of a viable seismic risk model at an urban or regional scale primarily depends on the quality of the inventory of the assets at risk (demography and manmade structures) within the study area. The building stock is the most important part of the inventory as it usually contributes in the highest proportion to the economic and social losses [33].At present, building information in Croatia that could be used in standard seismic risk assessment studies is very limited. The last census conducted in 20 I I [34] provides certain data such as the date of construction, occupancy category, number of dwellings, and number of people per dwelling. However, other information needed for a more comprehensive description of the building, e.g., construction material, structural type, number of storeys, etc., are not available.

\section{European regional inventory initiatives}

Significant efforts have recently been made towards development of a common European building inventory database [35]-[37], with the aim of describing the number and spatial distribution of different building typologies across Europe. Within the scope of the European FP7-funded project NERA (Network of European Research for Earthquake Risk Assessment and Mitigation), appropriate building stock information was generated for each country taking into account national census data on buildings or dwellings and records on construction practices conducted by respective statistical or financial services. The architecture of the Global Exposure Database [38-39], an initiative of the Global Earthquake Model (GEM), launched with the aim of building datasets, models and tools for the assessment of seismic risk on a global scale and to develop a supporting IT infrastructure [40], was used to store the European building information. The data available from various sources was examined and standardized to assign building attributes as identified within the GEM Basic Building Taxonomy [4I]. The protocol describes a building's attributes such as the construction material, type, height, structure quality, etc. and groups buildings with similar properties in respective categories of the standard classification scheme. 
The ongoing Horizon 2020 SERA project focuses, inter alia, on the improvement of the existing exposure models in Europe. In the scope of this project, the exposure model of Croatia consisting of information on residential, commercial, and industrial building occupancy classes in terms of building count, replacement cost and residential population, is also being updated with the contribution of Croatian experts in this field [42]-[45]. Four main residential buildings typologies have been identified: CR reinforced concrete dual wall-frame (estimated at $\sim 1 \%$ of the total building count), CR - reinforced concrete infilled frame systems ( $23 \%)$, MUR - unreinforced masonry wall systems ( $45 \%)$ and MCF - confined masonry wall systems ( 3I \%).

\section{Croatian local inventory initiatives}

Despite significant efforts that have been made in Croatia through the above regional projects, initiatives for seismic risk assessment still face significant challenges, particularly arising from the lack of data at the national, regional and/or urban scale. In the meantime, while awaiting the start of a systematic process for creating a comprehensive building database, some individual initiatives for detailed exposure models have already been initiated.

City of Zagreb: preliminary steps towards a standard building inventory database for the City of Zagreb have been undertaken within the disaster risk assessments [I], [46] and earthquake risk reduction studies [47] conducted in collaboration between the Faculty of Civil Engineering and the Zagreb Office for Emergency Management, implemented since 20I3. From the numerous activities and results generated by these studies, only the aspects associated with the building inventories will be presented herein.

As a first step, residential units were categorized using the information from the $20 \mathrm{II}$ census and considering typical construction periods related to respective seismic design codes. In addition to the distribution of residential units according to construction periods and seismic design codes, Table I also includes rough estimates of the expected seismic resistance of buildings, the information on structural analysis (lateral load) and dynamic load, and main parameters related to the vulnerability of buildings.

Further efforts were subsequently undertaken in collaboration with the Faculty of Architecture to divide the territory within the city limits into areas with characteristic distributions of standard building types (e.g., monolithic RC structures, prefabricated RC structures, masonry buildings with RC floors, masonry buildings with timber floors, etc.) and period of construction (Figure 6).

The ongoing detailed investigation for each of these areas involves acquisition of building information from existing documentation including statistical data, data from national registers, sample drawings, technical specifications, and photographs taken during construction and supplemented by field surveys when necessary. Certain difficulties have been encountered during this process, such as: lacking or incomplete architectural plans and design documentation; as-built plans significantly different from the approved initial design due to many structural interventions (reconstructions, 
Table I. Dwellings in Zagreb according to periods of application of particular design codes

\begin{tabular}{|c|c|c|c|c|c|c|}
\hline Period & before 1945 & $1946-1964$ & $|965-| 98 \mid$ & $1982-1998$ & $1998-20 \mid 2$ & from 2013 \\
\hline $\begin{array}{l}\text { Valid seismic } \\
\text { code }\end{array}$ & No code & $\begin{array}{l}\text { Temporary } \\
\text { technical code } \\
\text { for building } \\
\text { loads }\end{array}$ & $\begin{array}{l}\text { Ordinance on } \\
\text { Temporary } \\
\text { Technical } \\
\text { Regulations for } \\
\text { Construction } \\
\text { in Seismic } \\
\text { Areas }\end{array}$ & $\begin{array}{l}\text { Ordinance } \\
\text { on Technical } \\
\text { Standards for } \\
\text { Construction } \\
\text { of Buildings in } \\
\text { Seismic Areas }\end{array}$ & \begin{tabular}{|c|} 
transition peri- \\
od: acceptance \\
of European \\
Standards ENV \\
(Eurocode 8)
\end{tabular} & $\begin{array}{c}\text { European } \\
\text { Standards EN } \\
\text { (Eurocode 8) }\end{array}$ \\
\hline $\begin{array}{l}\text { Motivation for } \\
\text { code modifica- } \\
\text { tion }\end{array}$ & & & $\begin{array}{l}\text { Skopje earth- } \\
\text { quake } 1963\end{array}$ & $\begin{array}{c}\text { Montenegro } \\
\text { earthquake } \\
1979\end{array}$ & & \\
\hline Nr. of units & $\sim 40.000(\sim 13 \%)$ & $\sim 75.000(\sim 25 \%)$ & $\sim 87.000(\sim 30 \%)$ & $\sim 70.000(\sim 23 \%)$ & $\sim 40.000(\sim 13 \%)$ & few \\
\hline $\begin{array}{l}\text { Building seis- } \\
\text { mic resistance } \\
\text { (ER) } \\
\text { (rough clas- } \\
\text { sification by } \\
\text { structural type } \\
\text { and analysis } \\
\text { method) }\end{array}$ & $\begin{array}{c}\text { Buildings with } \\
\text { an initial level } \\
\text { of ER (mostly } \\
\text { masonry } \\
\text { buildings with } \\
\text { wooden floors, } \\
\text { since I } 920 \text { the } \\
\text { introduction of } \\
\text { RC floor) }\end{array}$ & $\begin{array}{c}\text { Buildings } \\
\text { with minimal } \\
\text { level of ER (RC } \\
\text { floors: partly } \\
\text { prefabricated } \\
\text { or constructed } \\
\text { in-situ, ma- } \\
\text { sonry buildings } \\
\text { without confin- } \\
\text { ing elements, } \\
\text { etc.) }\end{array}$ & $\begin{array}{c}\text { Buildings with } \\
\text { a low level of } \\
\text { ER (masonry } \\
\text { buildings with } \\
\text { horiz. and vert. } \\
\text { confining ele- } \\
\text { ments, } \\
\text { RC residential } \\
\text { buildings etc.) }\end{array}$ & $\begin{array}{l}\text { Buildings with } \\
\text { a medium level } \\
\text { of ER (masonry } \\
\text { buildings with } \\
\text { horiz. and } \\
\text { vert. confining } \\
\text { elements, RC } \\
\text { frames, RC, } \\
\text { etc.) }\end{array}$ & \multicolumn{2}{|c|}{$\begin{array}{l}\text { Buildings with a high level of } \\
\text { ER (masonry, concrete, steel, } \\
\text { wood, etc.) }\end{array}$} \\
\hline $\begin{array}{l}\text { Structural } \\
\text { analysis (hori- } \\
\text { zontal load) }\end{array}$ & $\begin{array}{c}\text { Earthquake } \\
\text { was not ac- } \\
\text { counted for as } \\
\text { an action, but } \\
\text { the horizontal } \\
\text { wind load was } \\
\text { defined }\end{array}$ & $\begin{array}{l}\text { Earthquake } \\
\text { was accounted } \\
\text { for by utilizing } \\
\text { simplified } \\
\text { methods (e.g. } \\
\text { concentrated } \\
\text { force at the } \\
\text { building top) }\end{array}$ & $\begin{array}{c}\text { First codes } \\
\text { for design of } \\
\text { seismic resist- } \\
\text { ance, } \\
\text { (seismic map of } \\
\text { 1964) }\end{array}$ & $\begin{array}{l}\text { Regulations, } \\
\text { modifications } \\
\text { and amend- } \\
\text { ments to codes } \\
\text { for design of } \\
\text { structures for } \\
\text { seismic resist- } \\
\text { ance (simple } \\
\text { rules, prelimi- } \\
\text { nary seismic } \\
\text { maps, 198I and } \\
\text { 1988) }\end{array}$ & \multicolumn{2}{|c|}{$\begin{array}{l}\text { Development and gradual } \\
\text { introduction of modern codes } \\
\text { for design of structures for } \\
\text { earthquake resistance, increase } \\
\text { of the seismic design loads }\end{array}$} \\
\hline Seismic load & $\begin{array}{l}<5 \% \text { EC8 } \\
\text { design load }\end{array}$ & $\begin{array}{l}<10 \% \text { EC8 } \\
\text { design load }\end{array}$ & $\begin{array}{c}30-50 \% \text { EC8 } \\
\text { design load }\end{array}$ & $\begin{array}{c}\text { 30-50 \% EC8 } \\
\text { design load }\end{array}$ & $\begin{array}{c}75-100 \% \text { EC8 } \\
\text { design load }\end{array}$ & $\begin{array}{l}100 \% \text { EC8 } \\
\text { design load }\end{array}$ \\
\hline $\begin{array}{c}\text { Causes of } \\
\text { building vulner- } \\
\text { ability }\end{array}$ & $\begin{array}{c}\text { Aging of ma- } \\
\text { terials, events } \\
\text { through history } \\
\text { (earthquakes, } \\
\text { fires, etc.), in- } \\
\text { sufficient initial } \\
\text { resistance, ex- } \\
\text { ceeded design } \\
\text { service life of } \\
50 \text { years, poor } \\
\text { maintenance, } \\
\text { particularly } \\
\text { endangered } \\
\text { cultural herit- } \\
\text { age }\end{array}$ & $\begin{array}{l}\text { Poor lateral re- } \\
\text { sistance, poor } \\
\text { construction } \\
\text { quality, poor } \\
\text { structural de- } \\
\text { tails, question- } \\
\text { able design }\end{array}$ & $\begin{array}{l}\text { Designed } \\
\text { for lower } \\
\text { seismic loads } \\
\text { - expected } \\
\text { damage much } \\
\text { larger than } \\
\text { anticipated in } \\
\text { design (pos- } \\
\text { sible collapse), } \\
\text { poor quality } \\
\text { of materials, } \\
\text { poor details, } \\
\text { incomplete } \\
\text { design, etc. }\end{array}$ & $\begin{array}{l}\text { Designed for } \\
\text { lower seismic } \\
\text { loads - ex- } \\
\text { pected damage } \\
\text { much larger } \\
\text { than antici- } \\
\text { pated in design } \\
\text { (possible col- } \\
\text { lapse), illegally } \\
\text { constructed } \\
\text { buildings, } \\
\text { adaptations, } \\
\text { improper } \\
\text { upgrading and } \\
\text { reconstruction } \\
\text { (additional } \\
\text { floors), poor } \\
\text { details etc. }\end{array}$ & \begin{tabular}{|} 
Mainly \\
designed for \\
seismic loads, \\
expected dam- \\
age larger than \\
anticipated in \\
design, illegally \\
constructed \\
buildings
\end{tabular} & $\begin{array}{l}\text { Complex, } \\
\text { poorly } \\
\text { designed build- } \\
\text { ings; buildings } \\
\text { with large } \\
\text { deviations from } \\
\text { the design } \\
\text { parameters } \\
\text { during con- } \\
\text { struction } \\
\text { (urban villas } \\
\text { built by inves- } \\
\text { tors for fast } \\
\text { profit); build- } \\
\text { ings (mostly } \\
\text { in northern } \\
\text { areas of the } \\
\text { city) built on } \\
\text { steep grounds } \\
\text { (landslides) }\end{array}$ \\
\hline
\end{tabular}


adaptations, enlargements) made following the construction, sometimes illegally and without any expertise, considerable deviation between design and final parameters as observed in numerous recent buildings designed according to modern codes (e.g., urban villas built for fast profit); numerous illegal buildings without any design or other documentation in municipal archives; etc.

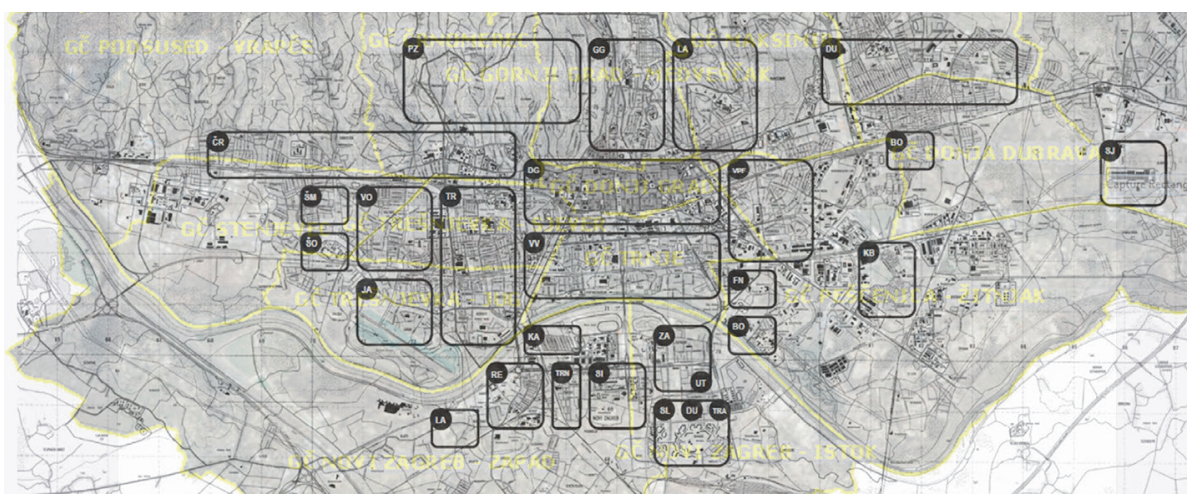

Figure 6. Map of Zagreb with labelled regions showing typical building types, according to [47]

In 2012, recognizing the problem of illegally built structures, the government passed the Act on Proceeding with Illegally Built Buildings for the purpose of legalising as many of those buildings as possible, and making the urban planning more efficient. After this Act came into force, more than 100,000 applications for legalization were submitted in the Zagreb region and more than 900,000 in Croatia. Attention should therefore be paid when creating inventory database of existing buildings, as the documentation/ visual screening conducted outside the building/aerial snapshots/google street view may give incorrect information.

Further efforts aimed at obtaining better exposure models were made in the scope of the update of the national risk assessment [46]. For the City of Zagreb, the following most common building types were defined: unreinforced masonry buildings (URM), buildings with reinforced concrete walls (RC2), concrete frame buildings with infills and confined masonry (RC4), large panel reinforced concrete buildings, so called "cans" (RC5), reinforced concrete mid-rise and high-rise buildings (NEB) combined with letters L (low-rise, I-3 storeys), M (mid-rise, 4-7 storeys) and $\mathrm{H}$ (high-rise, $8+$ storeys) added to describe the building height. Fourteen structural typologies included in the inventory are shown in Figure 7. The number of residential buildings associated with each structural type and their spatial distribution was determined for the city's 218 local communities (administrative units). The process was conducted in GIS environment and involved linking each building on the map with the respective structural type. In this way, the number of buildings has also been identified, which is very important for accurate risk assessment as only residential units are available from the census data. 
A considerable presence of mid-rise and high-rise URM buildings, a historic heritage from the period of the Austro-Hungarian Empire, was noted during the inventory. Given their historic significance, on the one hand side, and their potentially high vulnerability to dynamic loads on the other, the retrofitting of these buildings requires specific treatment and alignment to complementary seismic evaluation program, reconstruction guidelines and cost-benefit analyses.
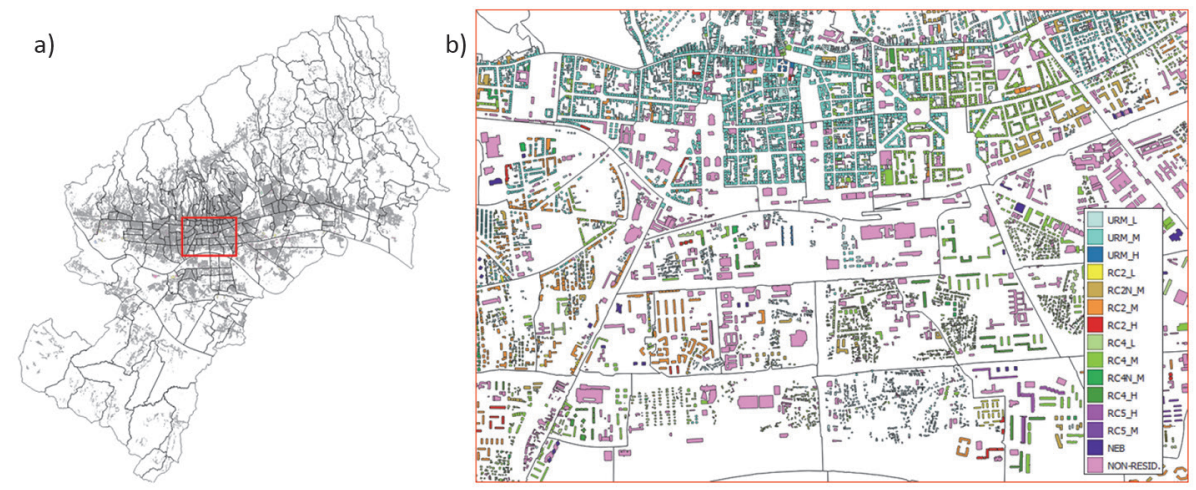

Figure 7. Inventory conducted for the City of Zagreb: a) local council limits, and b) spatial distribution of I 4 most common building types within the area marked with rectangle in a)

In the next step, the number of occupants was associated with each structural type to enable assessment of potential social losses: displaced households, shelter needs and casualties (injuries and fatalities). The last step consisted in evaluation of replacement costs for each building type. This was done according to the Standard calculation of building construction costs, the value of which differs from the market value of the building. The total replacement cost of the residential building stock was estimated at 37 billion EUR.

Following the above preliminary step towards a reliable exposure model for the City of Zagreb, it was concluded that a more granular building classification is needed in order to reflect more accurately the actual on-site conditions. A more refined categorization was therefore elaborated for the existing residential buildings stock. It consisted of a total of 42 building types based on the initial robust categories (i.e., URM, CM, RC2, RC3, RC4 and RC5), including additional attributes accounting for the structural system, construction period and specific local construction practices. In this respect, four construction periods accounting for different design categories (codes) were determined: PC before 1964 (precode); LC 1964-198I (low code - low seismic resistance), MC I98I-2005 (medium code medium seismic resistance and rigorous design conditions, e.g., ductility), and HC after 2005 (high code with graduate introduction and application of Eurocode 8).A detailed description supported with photographs was created for all types to enable easy identification of building stock properties and to allow non-experts to contribute to the inventory process. An example of the URM building type description is shown in Table 2 [47]. 
Table 2. Example description of URM_M_Tip building typology in Zagreb

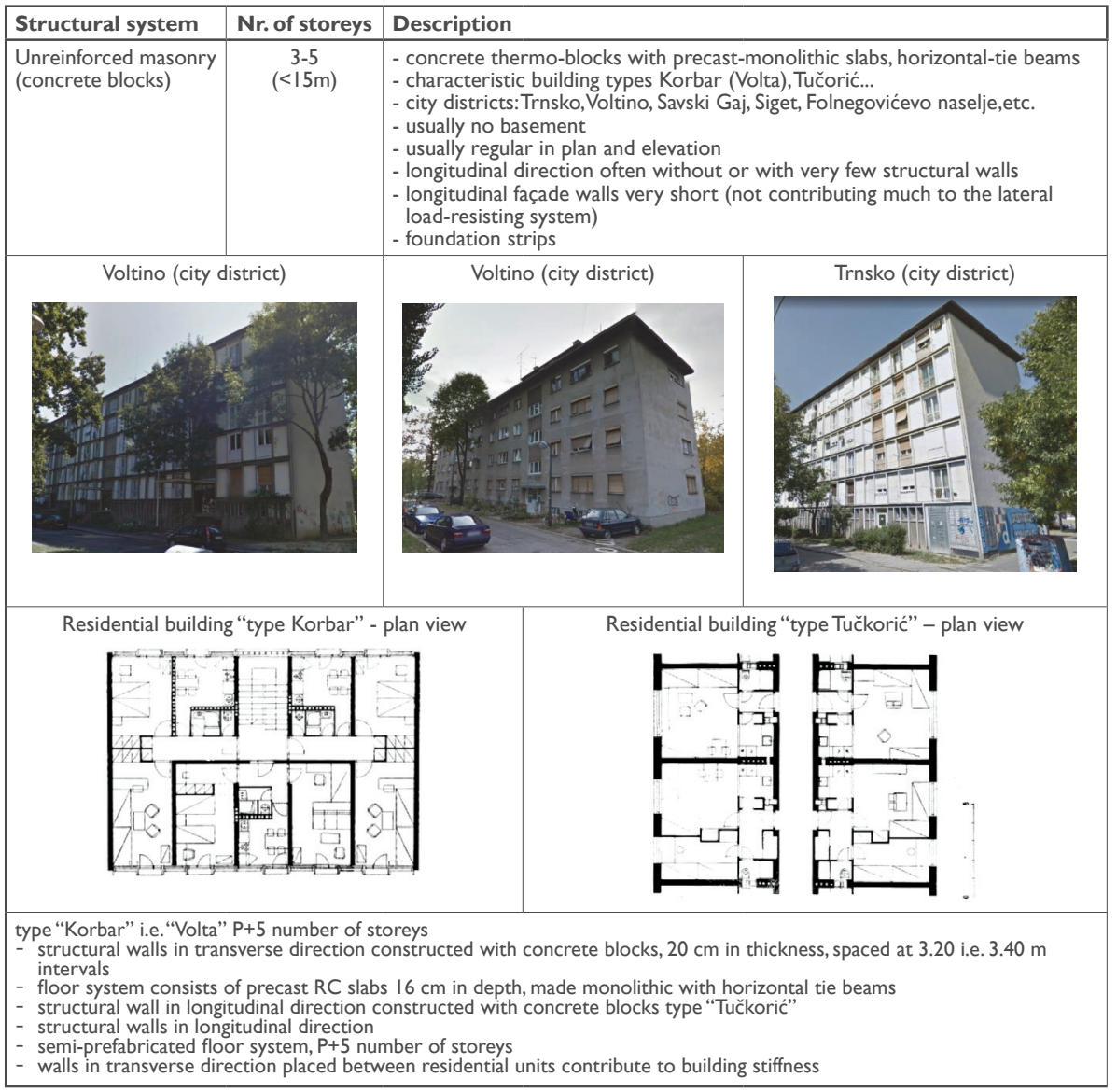

City of Osijek: Efforts have recently been made to create a database of the existing buildings in the City of Osijek, the fourth largest city in Croatia with approximately I 1 0,000 inhabitants. Currently, the database contains approximately I, I00 buildings and includes general data (building location, address, cadastral number, occupancy category, year of construction, position relative to the block), geometrical attributes (footprint dimensions, gross and net area, layout regularities, number of storeys, storey height, total height), main structural system, construction materials, and roof structure and cover [45].

Unfortunately, all these individual building inventory efforts (e.g., Zagreb, Osijek, historic centre of Dubrovnik [4]) cannot compensate for the lack of regularly updated national-level census data on the number and various structural attributes of existing buildings. As mentioned earlier, available national statistical data (year of construction, number of storeys, footprint, etc.) are related to dwelling units and not to buildings 
themselves and approximate equations for estimation of the number of buildings with respect to the number of dwelling units (e.g., those applied in GEM methodology) are inaccurate and usually calibrated at large scales, which is quite inappropriate for seismic risk assessment. Moreover, numerous renovations/reconstructions carried out in the past, which may have significantly affected lateral resistance of buildings, are usually not documented (e.g. creation of additional openings and demolition of often load-bearing bearing walls at ground floor level, performed mainly in historic city centres), nor does the documentation exist for illegally constructed buildings, the problem which Croatia has continuously been facing for a long time.All initiatives for a more reliable seismic risk assessment should have the same preliminary objective: to systematically create an adequate database of building inventory. It may be stated that the lack of appropriate building stock data is one of the biggest challenges affecting reliability of seismic risk assessment efforts, and the reliability of data in this segment should be of particular interest to local and national authorities.

\subsection{Seismic vulnerability}

Based on continuous improvement of methods for assessing seismic vulnerability of man-made structures (e.g., buildings, transport infrastructure, lifelines, critical facilities, historical monuments, etc.), an accurate quantification of physical vulnerability has been recognised as being fundamental for the development of reliable models for assessing economic and social losses from future earthquakes [25]. The vulnerability of a structure is described using:

- vulnerability functions, defined as the probability of losses given intensity of structural response or ground shaking

- fragility functions, representing the probability of exceedance of various limit damage states, given intensity of structural response or ground shaking [48].

Various methods for the development of seismic vulnerability functions can be divided into three fundamental categories: empirical methods, analytical methods and expert-opinion based methods, which may be combined as appropriate [49]. Qualitative damage scales based on post-earthquake damage statistics are often used in empirical methods. Analytical methods, however, rely on numerical simulation of seismic performance of structures against increasing levels of excitation, where damage is associated with mechanical properties related to structural limit states (e.g. interstorey-drift capacity). Detailed reviews of various vulnerability assessments methods have been provided by many authors, for instance in [25], [48], [50], [5I]. Analytical methods, often validated with large-scale experimental data, have become increasingly popular in recent years, as this approach does not depend on the availability of well documented post-earthquake damage observations [50]. Detailed guidelines on the derivation of fragility curves using this approach can be found in [52]. Simplified rapid assessment techniques are applied for vulnerability assessment at urban level, thus avoiding the time consuming vulnerability evaluation for each building in the study area [53]. Notable advances in the development of 
local inventory databases and integrated methods and tools for systemic seismic vulnerability assessment and risk analysis of man-made structures have been achieved within the SYNER-G European collaborative research project [48]. However, despite numerous studies and huge quantity of data generated in the process (e.g. [54]-[60]), the information on vulnerability of specific building types needed for seismic risk assessments at the local level is still lacking. Due to differences in seismic regulations, availability of materials, and construction practices, the built environment differs considerably in various countries, and so vulnerability functions developed for a given region cannot be directly used in another region. In this respect, local inventories and respective vulnerability datasets should be introduced based on specifics of the study area and should strongly rely on local expertise.

Difficulties in the development of reliable assessment of physical vulnerability of the built environment in Croatia are directly related to the absence of standardized comprehensive exposure models. It is therefore obvious that without accurate information on the assets at risk, it is extremely difficult to assess the expected seismic performance of structures and the respective damage state for a given seismic excitation. Proper attention should therefore be paid to the selection of an appropriate approach for the development of vulnerability functions as, despite the relatively high seismicity in Croatia, well documented earthquake damage observations that can be used to calibrate analytical models are still rather limited. In addition, numerous unknowns exist regarding dynamic properties of the existing building stock, although that would be a necessary input in sophisticated numerical models. Based on the preliminary building inventory for the City of Zagreb discussed in the previous section, it can be concluded that considerable portion of the building stock is highly vulnerable to seismic excitation. Most residential buildings were built before the introduction of the seismic codes. In particular, those built before 1964 were not explicitly designed to sustain earthquake load although, depending on the structural system used, they can show certain initial seismic resistance. In subsequent years, depending on the location of the structure, design seismic loads were several times lower than those prescribed by current standards. It was assumed when Eurocode 8 was officially introduced in 2013 that the newly built structures will satisfy seismic demands related to different limit states (100\% of the seismic load). However, these buildings make only a small portion of the residential building stock.

\section{Simple method for development of fragility curves}

A relatively simple but rough method for the development of fragility curves for fourteen most common types of structural systems in Zagreb is presented herein. The spatial distribution of each of the fourteen residential building types and the total number for each of the 218 local communities, were discussed in the previous section (Figure 7). Individual sets of fragility curves were derived for each building type using macroseismic method in accordance with the RISK-UE project [6I]. Damage classification was made according to the EMS-98 damage scale [62] with five damage states (slight, moderate, extensive, complete, and collapse).The mean damage 
state function was calculated on the basis of the macroseismic intensity and the vulnerability index [63] ranging from 0.246 to 0.82 for the analysed building types. The damage probability matrix corresponding to the mean damage state for successively increasing intensities was developed in the initial stage, and the macroseismic intensity was then transformed to PGA using the relationship proposed in [64]. In this way, the existing seismic hazard information for PGA for Zagreb could be used as input in the vulnerability assessments. The discrete values of the damage probability matrix were fitted using the lognormal cumulative probability distribution to derive continuous fragility functions (Figure 8). Damage factors (DF) were then assumed in order to correlate economic losses to the expected structural damage. DFs associate the cost of repair for each damage state to the total replacement cost of the building. Thus, vulnerability curves were obtained for each building type by convolving building fragility curves with the cumulative cost of a given damage state according to [52]. These vulnerability curves for characteristic building types represent the basis for estimation of economic losses and fatalities for seismic scenarios in Zagreb, discussed in the next section.
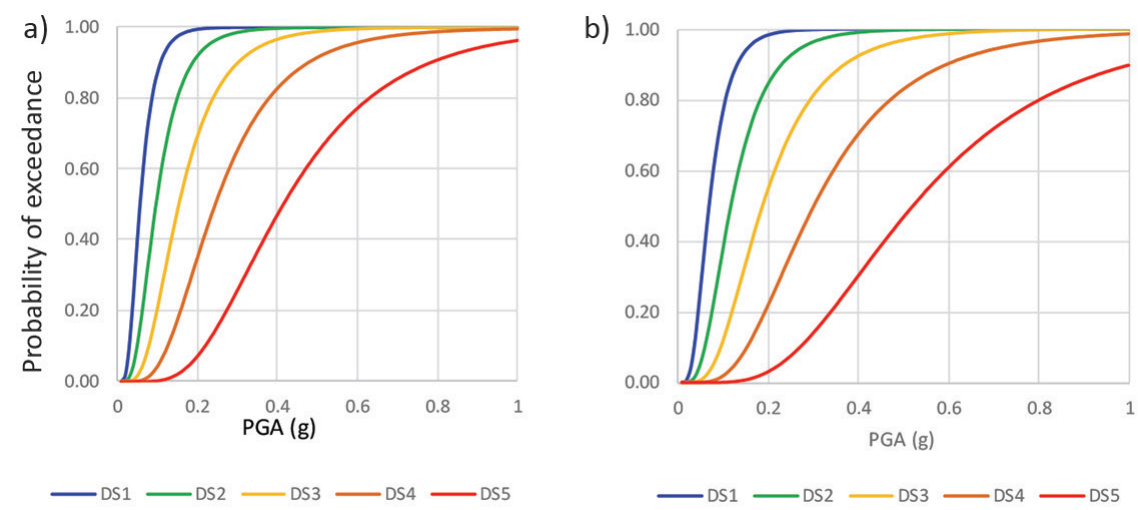

Figure 8. Fragility curves for building types: a) URM_L and b) RC4_H

\section{Numerical vulnerability analysis at building scale}

Vulnerability analyses of individual buildings with specific local features (e.g., semiprefabricated RC structures, structures built using tunnel formwork, specific local masonry residential buildings, etc.) were performed in parallel to the above activity, in order to determine a more detailed seismic performance of buildings (Figure 9). After the form-based preliminary vulnerability assessment, the performance of these buildings was evaluated using complex three-dimensional numerical models. Experimental measurements of dynamic parameters using ambient vibrations were made for most of the considered buildings. Field data were important for model calibration and verification of the as-built state, since extensive experimental investigations of material properties were not possible. 
Critical structural elements in each analysed building were identified and described based on numerical and experimental results. This information could be helpful for eventual seismic retrofit and for post-earthquake damage assessment. In addition, the results generated and the data collected in the analysis are currently being adjusted to the needs of disaster response teams, and are gradually being implemented in the system of decision-making and preparedness in the event of a natural disaster in Zagreb.

a)

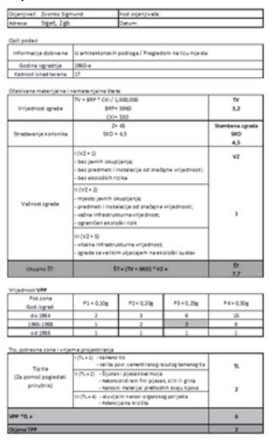

b)

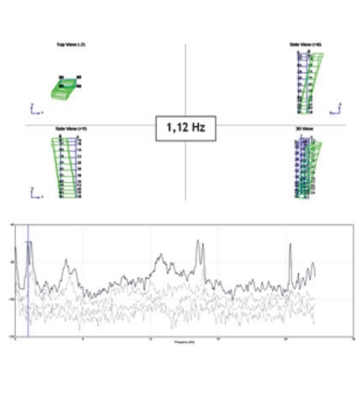

c)

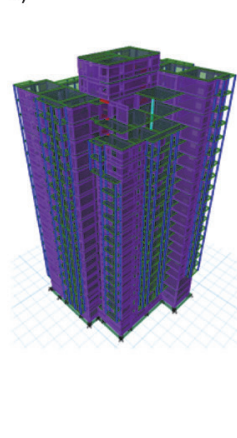

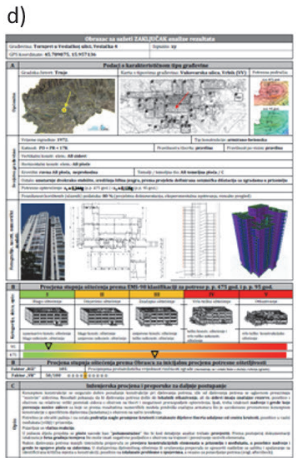

Figure 9. Analytic approach for a building based on acquired data: a) form for initial vulnerability assessment, b) experimental determination of dynamic parameters, c) numerical model and d) form for building analysis summary [65]

Results of numerical analysis for a residential building from the 1950s, protected as cultural heritage, will be briefly presented herein as a typical example of performance of the local building stock in Zagreb. The considered building is irregular both vertically and horizontally, and there are only a few load-bearing shear walls in longitudinal direction (Figure IOa). This building was analysed in detail based on a three-dimensional nonlinear numerical model. Nonlinear static and dynamic analyses were performed using a set of earthquake acceleration records generated for deterministic scenarios and a set of records compatible with the Eurocode 8 spectrum for the location, considering different return periods and the corresponding levels of PGA.The pushover curve generated in longitudinal direction is shown in Figure IOb as one of typical results that are useful for determining the performance point for a given seismic demand (dynamic response of the building). The obtained base shear force value of $1100 \mathrm{kN}$, corresponding to the limit state for significant damage, amounts to less than $3 \%$ of vertical load. Figure $10 \mathrm{~b}$ shows the hysteretic response of the shear force in the critical structural wall of the 3 rd storey with synthetic acceleration record, and with peak ground acceleration scaled at $0.15 \mathrm{~g}$ as seismic excitation. It can be observed that the wall reaches its capacity even for low seismic excitation with PGA of $0.15 \mathrm{~g}$, which may result in local collapse of the floor system above. This is a much lower PGA level than the 
one corresponding to the limit state of significant damage $(0.247 \mathrm{~g}$ for a 475 years return period). It may thus be concluded that the considered RC building exhibits significant vulnerability and should be seismically retrofitted. More detailed analysis results and preliminary retrofit solutions are discussed in [66].
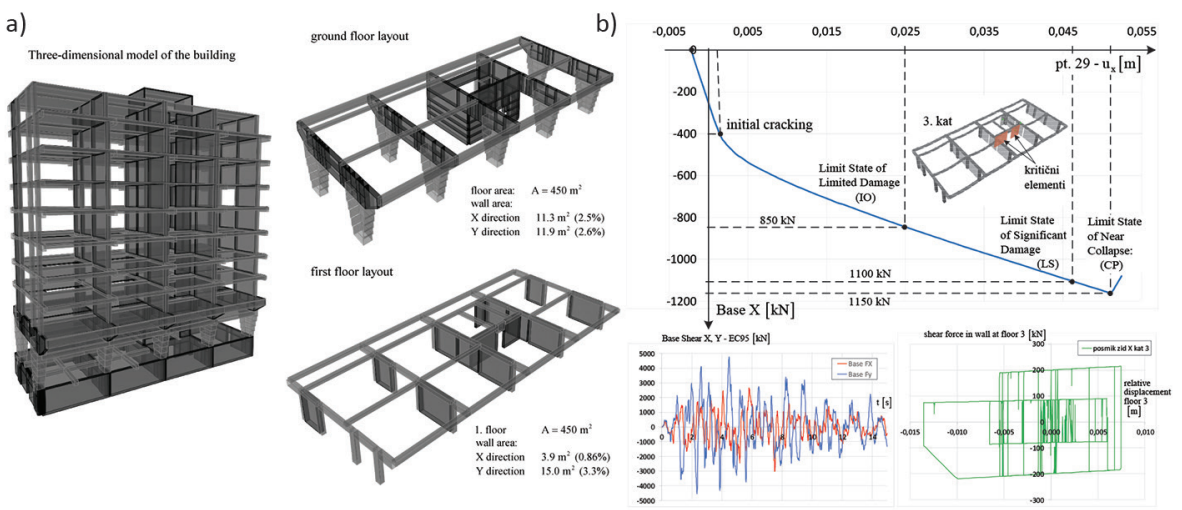

Figure 10. RC residential building in Zagreb: a) numerical model and structural layout of ground floor and first storey, and b) numerical results: pushover curve in longitudinal direction, and base shear and shear force in structural wall of the $3^{\text {rd }}$ storey for synthetic acceleration record with PGA=0.15g [66]

In addition to the study of vulnerability of the building stock in Zagreb, appropriate vulnerability analyses have been also performed for the building stock in Osijek (e.g. [67-69]).

\section{Vulnerability analyses for essential facilities and other important structures}

Unlike vulnerability assessments of residential building stock that are usually performed at urban or regional scales, the seismic vulnerability of structures of strategic importance is mainly analysed individually depending on the needs and especially on the consequences that would result from the damage or collapse of these structures. More than $40 \%$ of buildings in Croatia were built more than 50 years ago [34], and so their normal service life has already been exceeded. Unfortunately, this is especially true for essential facilities, such as hospitals, schools, kindergartens, university buildings, government buildings and buildings of public and social significance, fire and police stations, emergency operation centres, etc. Although often older than 100 years, these facilities and related parts of community infrastructure have to remain operational or should be restored rapidly after a strong earthquake. Therefore, accurate vulnerability assessment of selected critical infrastructure elements should be carried out on the basis of extensive individual analyses for each structure. Furthermore, there are a number of features related 
to cultural heritage and construction practices in Croatia that require special attention. Good examples are city centres of historic Dalmatian towns which are, in addition to their historical and cultural importance, still heavily occupied, while many important institutions are still situated in buildings that were built centuries ago. Such city centres were often built of stone masonry in aggregates, in a block of connected buildings. Built to resist gravity loads only, the seismic vulnerability assessments of such structures constitute a particular scientific and technical challenge.

Among a number of Croatian historic cities, a special emphasis should be placed on the city of Dubrovnik as it has suffered great devastation by earthquakes throughout its history. A vulnerability study was recently conducted in the scope of the "Resilience Enhancement of ADrlatic basiN from firE and SeiSmic hazards - READINESS" project and in collaboration between the University of Zagreb, Faculty of Science and the University of Zagreb, Faculty of Civil Engineering [70]. It consisted of instrumental measurements of dynamic parameters (fundamental period and damping) of fifteen strategic public buildings (SPBs) and it also involved measurement of resonant frequencies of underlying soil. These measurements led to identification of the soil-building resonance risk effects. Additional visual screening was conducted for five strategic public buildings (schools) as a basis for the preliminary damage assessment according to EMS-98 damage scale. The knowledge generated in this context will be important for mitigating seismic risk in the Dubrovnik-Neretva County. A detailed seismic performance assessment project for a hospital building was carried out in the scope of the project. The building $D$ of the General Hospital Dubrovnik, considered as the key facility for provision of hospital services and rescue actions after potential earthquakes, was analysed with a state-of-the-art approach using detailed numerical and experimental analyses [7I]. The study comprised seismological ambient noise measurements, continuous instrumental measurements using seismometers, definition of seismic hazard at the location and generation of artificial and simulated acceleration records, experimental testing of dynamic parameters, numerical analyses based on three-dimensional finite elements numerical models (Figure Ila), and analytic methods of various levels of complexity. Detailed models that included material nonlinearities of structural elements were developed for application of non-linear static and dynamic methods that are capable of capturing performance of buildings during severe seismic shaking. Only a few characteristic results are presented below. Readers are referred to the study report given in [7I] for a more detailed information.

The hospital building under study is asymmetrical in plan, and is subjected to significant torsional effects. Pushover curves (Figure II b) were determined by nonlinear static procedure separately for every horizontal direction, thus accounting for both positive and negative directions and various loading patterns. This procedure enabled identification of various collapse mechanisms. 

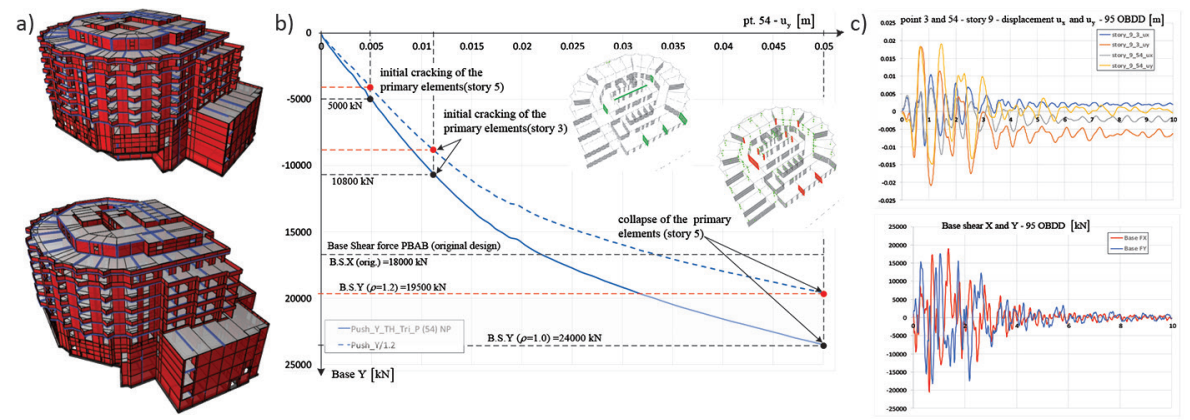

Figure I I. Building D of the General Hospital Dubrovnik: a) numerical model, b) pushover curve (base shear $Y$ ) with marked thresholds for limit states, and c) top displacements $u_{x}$ and $u_{y}$, and base shear for deterministic earthquake scenario of 95 years $[7 I]$

The response of the building structure to representative earthquake scenarios was determined by the piecewise exact step-by-step method using accelerograms generated by two different approaches. In the scope of the first one, synthetic earthquake accelerograms were matched to a specific target response spectrum and in the second approach, the accelerograms were simulated for four deterministic earthquake scenarios for the building location in accordance with seismic hazard estimated by the PSHA procedure for four return periods of interest. Prescribed requirements and limit states corresponded to the defined earthquake return periods. In addition to the above earthquake scenarios, scenarios with PGA ranging from $0.1 \mathrm{~g}$ to $0.16 \mathrm{~g}$ were also investigated for damage limitation state. Some of the results for the set of input accelerograms simulated for the location within the deterministic earthquake scenario with PGA of $0.16 \mathrm{~g}$, and with the return period of 95 years, are presented in Figure I Ic. Building collapse mechanisms and critical structural elements were identified and specific measures for target retrofit were proposed based on the results. In addition to prevention measures, results of the assessment can also be used to facilitate post-earthquake procedures (e.g. damage assessment and evaluation of load-bearing capacity), particularly for situations in which rescue of the victims has to be initiated by search and rescue intervention teams and when partial collapses have to be resolved. The "safe" areas have been identified for this purpose. All these results clearly show that the vulnerability of similarly important and complex buildings cannot be evaluated by simplified procedures that are used for assessment of building stock at larger scale (e.g. urban, regional, national).

Certain strategic buildings in Zagreb, such as hospitals, fire stations, industrial buildings, student dormitories, schools, concert hall, national theatre, city hall building, bridge, etc. were analysed in the scope of the Study on earthquake risk reduction in the City of Zagreb [47] (Figure 12). 

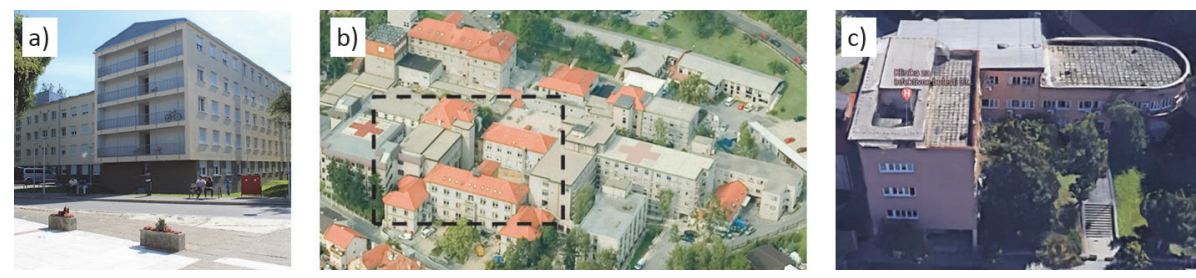

Figure I2. Examples of individually analysed important buildings (a. student dorm, b. Clinical Hospital Sveti Duh, c. Hospital for Infectious Diseases Fran Mihaljević) [47]

Among these, hospitals will be briefly presented in this paper, as most of them were designed and built before any seismic regulations. On the other hand, most of them have experienced numerous undocumented reconstructions and extensions over their useful life, which has in many cases disrupted and degraded the initial structural system. Within the study, seismic performance assessment using three-dimensional numerical models and experimental testing of dynamic parameters was performed for buildings in three hospital centres: Sveti Duh (4 buildings were analysed), Sisters of Mercy ( 6 buildings were analysed) and Fran Mihaljevic (one building was analysed). Most of these buildings are assumed to be highly vulnerable to potential earthquake motions and have to be seismically retrofitted. Detailed results are discussed in [47]. At the same time, it was observed that hospitals do not have sufficient capacities for the number of victims that can be expected in case a strong earthquake occurs in Zagreb [46].

Another unfortunate fact is that most of the hospitals in Zagreb are located in the northern part, which is the oldest and most vulnerable part of the city. In addition, it is presumed that the traffic connection with other parts of the city, especially connection with the south portion of Zagreb that is separated by the Sava River, will be inadequate in case of a disastrous event. For an efficient emergency response, it is essential to adequately define evacuation routes with critical elements that are seismically not very vulnerable (e.g., bridges and overpasses) and to take into account potential secondary consequences (building collapse, landslides, liquefaction, etc.) which may limit passage and significantly slow down interventions (search and rescue, evacuation, debris removal, damage inspection, etc.). Currently, the suggested evacuation routes extend mainly in the east-west direction while the south-north corridor is not covered, mainly because of poor condition of bridges over the Sava River. In fact, there are nine road bridges in Zagreb and the surrounding area.They are of strategic importance as, besides traffic, they conduct critical lifelines (fresh water, gas, and electricity). Only three of these bridges were designed according to modern seismic regulations and significant damage or collapse of the remaining bridges may cause considerable indirect losses.According to available data and observed condition of the bridges, some of them are in need of urgent seismic retrofit. As is often the case, an organized system of investing in infrastructure maintenance and upgrade is practically inexistent due to lack of funding, and so a seismic retrofit programme is 
even not considered at the moment. If such a programme is to be implemented, the detailed seismic analyses of all strategic structures located in the earthquake-prone regions of the country should constitute its first step.

Besides essential and transport facilities, the vulnerability of other critical structures have to be taken into account, such as hydroelectric and thermal power plants and the associated power transportation grid. Dams also pose a very high risk to surrounding areas and inhabitants. Furthermore, an important component to be accounted for is the highway and railway transport network, which is crucial in post-earthquake situations, with mountainous areas being particularly vulnerable because of possible landslides.All these facilities are necessary for the fastest possible recovery to normal conditions in earthquake-affected areas.

\section{Seismic risk assessment studies}

Potential negative impacts from earthquakes include:

- damage to buildings, infrastructure and environment,

- direct and indirect economic losses and, what is the most important,

- social losses in terms of displaced households, shelter needs, and casualties including fatalities and all types of injuries.

Although earthquake losses depend on numerous factors and vary widely, their approximate prediction provides critical information for making informed decisions about development of emergency response, recovery and risk reduction plans. Structural damage, discussed in previous section, is commonly used as the basis for calculation of other losses. Economic losses are calculated using damage-loss models, which provide an estimation of the mean repair/replacement cost for each state of damage. To this end, damage factors defined as a percentage of replacement cost are introduced for each damage state of structures. The probability of fatalities, on the other hand, is generally correlated to the probability of structural failure and the number of collapsed buildings. Hence, the number of fatalities is estimated using the ratio of the number of fatalities to the number of occupants (based on observations from past earthquakes). Since the number of collapsed buildings is considerably lower than the number of damaged buildings, structural failure constitutes less than $10 \%$ of non-fatal injuries, which are usually provoked by non-structural elements and various contents of buildings [72]. This is particularly true for earthquake-resilient buildings designed using modern building codes, where the occurrence of structural failure is not common. Human behaviour during and after earthquake shaking is also an important factor as it influences the number of injuries, e.g., running down the stairs and rapidly exiting a building increases the likelihood of falling or being struck by a falling object.

Regarding the existing seismic risk assessments at a global level, the Global Earthquake Model (GEM) published the "Global Seismic Risk Map” product (v20 I8. I) [73] which contains: 
- Exposure Map depicting the geographic distribution of residential, commercial and industrial buildings,

- Seismic Hazard Map depicting the geographic distribution of the Peak Ground Acceleration (PGA) with a $10 \%$ probability of exceedance in 50 years at reference rock conditions (shear wave velocity of $760-800 \mathrm{~m} / \mathrm{s}$ ),

- Global Map presenting the spatial distribution of average annual loss (US\$) in residential, commercial and industrial buildings normalised by the average construction costs in respective countries (US $\left.\$ / \mathrm{m}^{2}\right)$,

- Global Seismic Fatalities Map depicting an estimate of average annual human losses due to earthquake-induced structural collapse of buildings.

These maps are continuously being updated with additional increasingly accurate datasets and models. According to GEM estimate (Figure I3), the region with the highest seismic risk in Croatia is the City of Zagreb with an annual average loss of 35 million US\$, followed by the Split-Dalmatia County with approximately I 5 million US\$/year, and the Primorje-Gorski Kotar County with approximately II million US\$I year. Based on GEM estimate, which is currently the only state-of-the-art assessment of financial losses for the whole country, the total economic loss for Croatia can be estimated at US\$ I0I.8 million/year. GEM's tendency is to provide globally applicable models. However, the reliability of such outputs needs to be further increased through introduction of detailed information based upon local expertise.
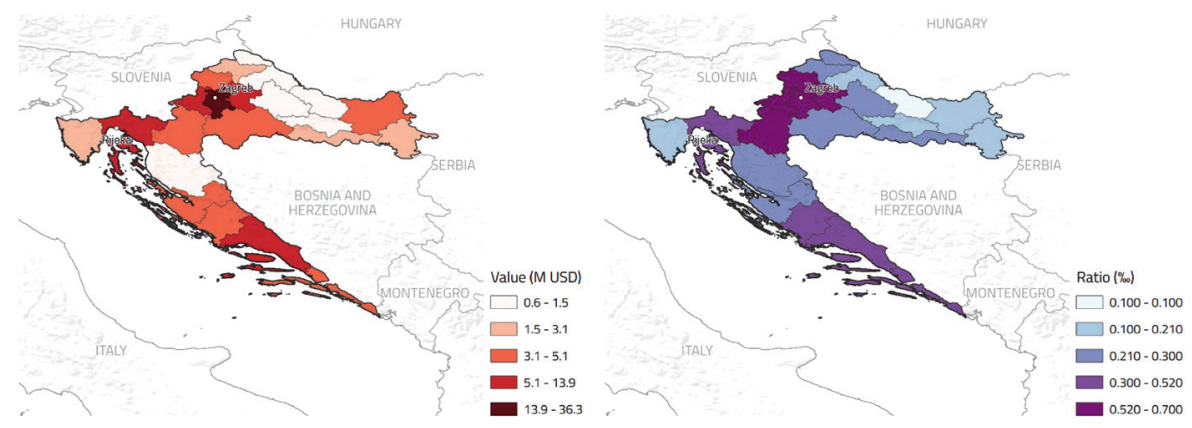

Figure 13. Predicted average annual losses and average annual loss ratios caused by earthquakes in Croatia [73]

At the national scale, risk assessments for the whole country, counties, cities and municipalities are prescribed by law (including seismic risk as one of such risks). Currently, risk assessments are performed according to an older ordinance on the methodology for vulnerability assessments [74], while the assessments in conformity with the more recent ordinance [75] are being conducted and harmonized with European Commission guidelines. Existing documents include mainly general information generated with methodologies and expertise unevenly distributed across 
various administrative units. The data acquisition for appropriate building parameters is reiterated since this step is critical for more accurate seismic risk assessments. The need for systematic building inventories and application of reliable risk assessment procedures became obvious in 2013 when Croatia received the European Commission directive to implement Risk Assessment and Mapping Guidelines for Disaster Management (Brussels, SEC (2010) 1626), with the aim of achieving harmonization of methodologies and allowing comparison of risk assessment outcomes between member states. The government assigned the coordination task to respective ministries and to the National Protection and Rescue Directorate through Croatian Platform for Disaster Risk Reduction, which further involved relevant scientific institutions through working groups. The Faculty of Civil Engineering in Zagreb was appointed as the lead executive for the seismic risk assessment with the objective of supporting the initiative through various research investigations. To this end, a document entitled National Disaster Risk Assessment in the Republic of Croatia - Seismic Risk [I] was prepared in 2014 for the Ministry of Construction and Physical Planning and for the National Protection and Rescue Directorate of Croatia. This document was prepared according to specified guidelines with predetermined scenarios and output risk matrices. Disaster categories and values were adjusted to other natural disasters identified in Croatia (e.g., floods and wildfires) to allow comparisons on a common ground and, ultimately, to formulate respective risk management policies. For example, a disaster category 5 (the highest category according to consequences) was determined as the one that affects more than I,500 people and/or results in economic losses in excess of 7,000 million HRK ( 950 million EUR). This excessively robust assessment was sufficient to satisfy these officially prescribed categories of consequences and the completion of the risk matrix. During the assessment, it was recognized that building inventory data are far from the format that would be usable for risk assessment procedures, and that existing databases are highly uncertain (e.g. because of numerous illegal construction practices and interventions on existing buildings).

In 2018, during preparation of the Updated risk assessment of natural disasters in Croatia - Seismic Risk report [30], some efforts were made towards creating a better exposure model and a more reliable risk assessment procedure. In this document, the Seismic hazard was considered in accordance with the current seismic hazard for Croatia [3I]. For instance, two earthquake scenarios were defined for the City of Zagreb: (i) earthquake event with the worst-possible consequences, and (ii) the most probable unwanted earthquake event. In this respect, PGAs for return periods of 475 and 95 years were determined as seismic input for risk assessment of municipal administrative buildings. Local site effects and potential amplification of seismic shaking were not considered since results of the ongoing microzonation study are still not available for the entire study area [76], [77]. One of the deterministic scenarios considered in the study was the historic 1880 M 6.3 Great Zagreb Earthquake with the epicentral distance of about $17 \mathrm{~km}$ to the north-east of Zagreb downtown and with the depth of $16 \mathrm{~km}$. Principal ground motion parameters were generated by applying the empirical ground motion prediction equation proposed by Akkar and Bommer [78]. The seismic 
risk assessment was then conducted using the set of fragility curves for fourteen common building types, some of which are shown in Figure 8. Estimated damage to residential buildings and respective economic and social losses were calculated at the local community scale. Characteristic results of the expected economic loss for the worst-case hazard scenario with a return period of I/475 years [46] are presented in Figure 14 in the form of spatial maps made in QGIS [79].

Official national seismic risk assessments [1], [46] point to unacceptable seismic risk with disastrous consequences, which runs beyond the criteria adopted from the European Commission. These consequences in fact exceed potential losses from other hazards identified in Croatia [80]. A strong earthquake, capable of inflicting great damage to the building stock in the affected area and depriving citizens of their living space and employment, could cripple the fragile economic state of our country, additionally increase emigration, and endanger social and political stability.

In conclusion of this section, it should be emphasized once again that reliable assessment of economic losses and casualties depends on the accuracy of three input parameters: seismic hazard, exposure, and physical vulnerability. The current state of knowledge is unsatisfactory for all three parameters and the activities proposed to address these issues are summarized in Section 5.
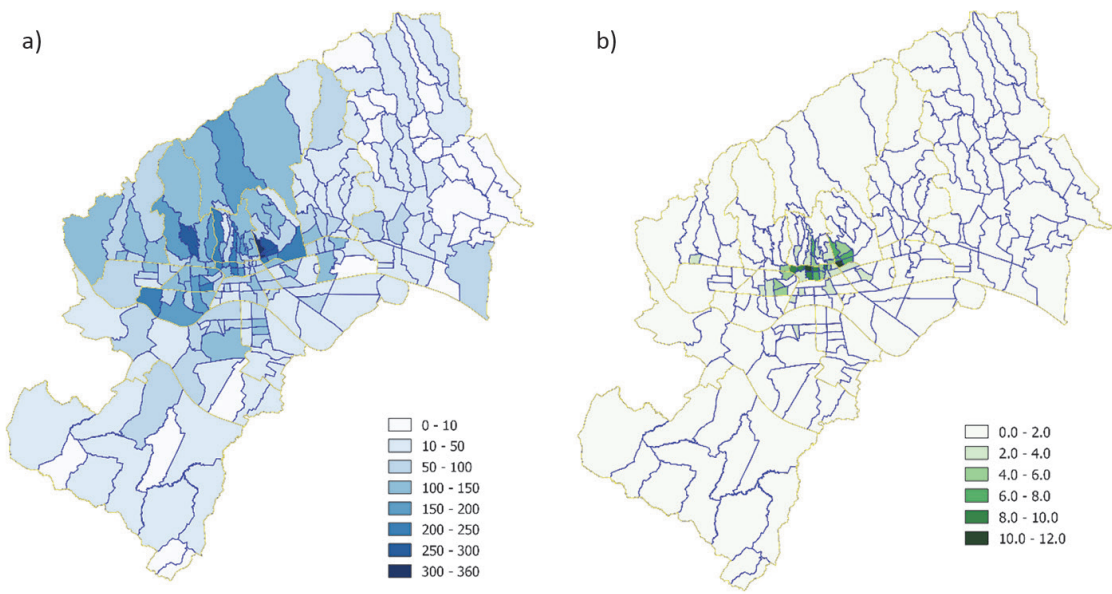

Figure 14. Economic losses in millions of euros at the local community scale derived from damage to residential buildings for the worst-case probabilistic hazard scenario with a return period of $\mathbf{4 7 5}$ years: a) total economic loss, and b) economic loss per hectare

\section{Seismic risk reduction activities}

The seismic risk assessment process provides predictions of potential negative consequences from future strong earthquakes, which can be quite significant in Croatia. These assessments, however, represent only the first step in setting priorities for 
consecutive risk reduction strategies. One of potential measures that could be adopted is the seismic retrofit of the most vulnerable structures. The retrofitting process, unfortunately, takes time and significant financial resources. Thus it is not expected that the process will be completed in the near future, although cost-benefit analyses demonstrate up to eight times the value of initial investment, e.g. US FEMA https:// www.fema.gov/benefit-cost-analysis. In the meantime, the focus should be placed on complementary disaster risk reduction measures that have also been recognized as essential. Such measures mainly include the activities of Civil Protection teams, which is the key for fast and effective post-earthquake assistance, especially if a strong earthquake generates numerous fatalities, injuries, trapped people, and results in destruction of residential and industrial facilities, disruption of supply lines and health care services, etc. In Croatia, numerous volunteers and associations take part in civil protection, for which a step forward could be achieved by identifying and applying particular expertise. For example, experts-engineers could significantly contribute to postearthquake damage assessment of buildings and help in making certain decisions within safety teams, e.g., whether entering a damaged building is sufficiently safe [8I]. In such situations, engineers are able to rapidly recognize and distinguish damage to building structural elements from damage to non-structural elements and amenities. Given the level and extent of damage, engineers can also detect the potential for further development of a structural collapse mechanism. In case of a bearing wall failure, engineers will more easily recognize the capacity of other supports within the structure, and suggest proper procedures for collapse prevention. In addition, optimal breaking/breaching and shoring/propping, and selection of alternative evacuation and transport routes (e.g., in case of bridge damage), may also be in the scope of the work to be undertaken by engineers within intervention teams.

The engineering expertise is traditionally used for post-earthquake damage assessment of buildings as an important aid in the decision-making process. Such technical estimates on the level of damage and building safety enable informed decisions on the usability of buildings:

- usable (green tagged buildings with no or slight damage),

- temporarily unusable (yellow tagged buildings with moderate damage that need repair prior to the return of occupants),

- unusable (red tagged buildings with extensive or total damage for which final decision on demolition or repair should be made).

These decisions directly affect the population and largely determine sheltering requirements. Following a strong earthquake, a large number of requests for inspection of buildings and other infrastructure usually arrive in a short period of time, so that effective and quick post-earthquake surveys are of utmost importance for the restoration of normal conditions. The assessment of usability of a system is a sensitive and responsible task, and most of the earthquake-prone European countries have been developing for decades appropriate survey procedures, damage assessment forms, and training procedures. Some individual efforts in that direction have also been made in Croatia. For example, forms for post-earthquake damage assessment 
of buildings, with respective guidelines, have been prepared, mainly based on Italian experience and relating to the local building stock (Figure I5).
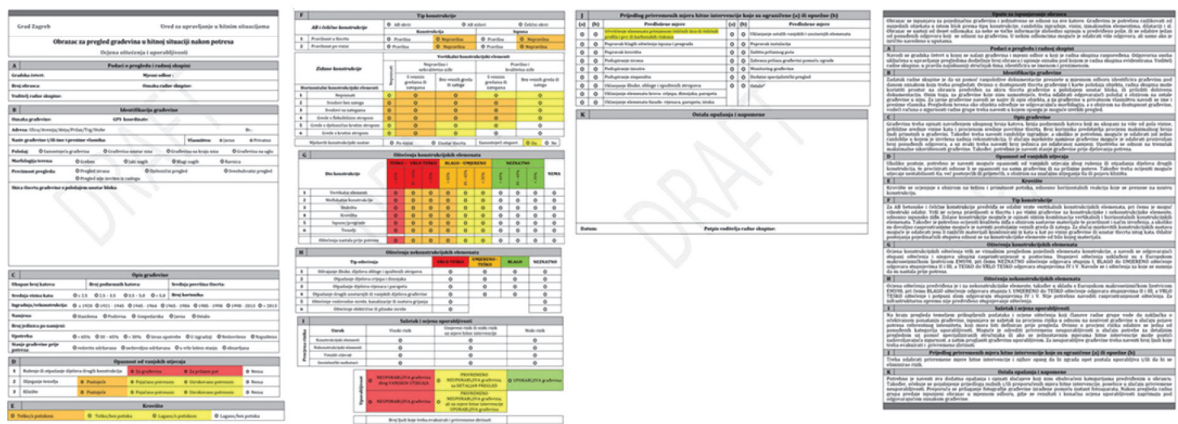

Figure 15. Form for post-earthquake damage assessment of buildings with guidelines (in Croatian)

Similar forms were developed for post-earthquake assessment of bridge functionality based on the US methods with respect to different levels of visual inspection [47]. These forms have been updated according to local experience from joint exercises with engineers and intervention teams. During these exercises (Figure I6a-b), it was observed that rescue staff needs to fully understand vulnerability of different buildings and, especially, to recognize weak structural elements in specific building types. The training curriculum for firefighters and engineers is currently under preparation in collaboration with the Zagreb City Office for Emergency Management.
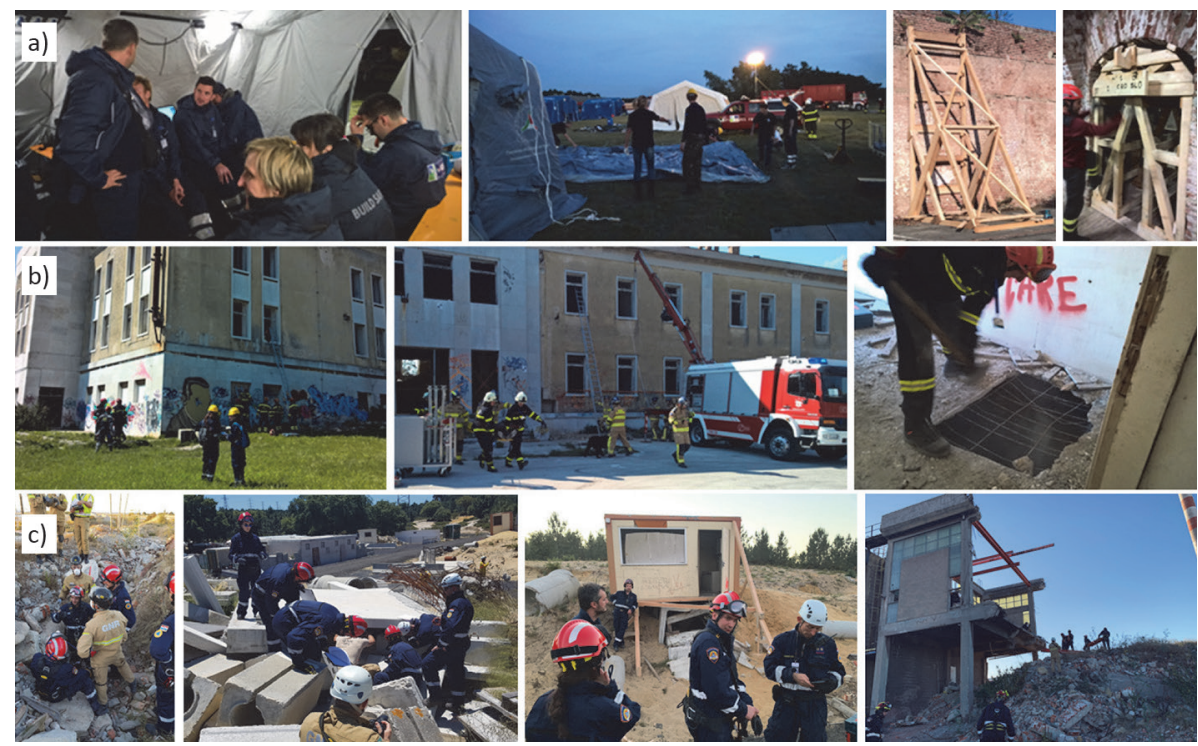

Figure 16.Training sessions and joint exercises with intervention teams: a) Alessandria 2015, b) Istra 2017, and c) Cascade 2019 
The introduction lecture for firefighters has been held with the aim of discussing potential role of engineers from different points of view. For that purpose, a hypothetical disaster scenario was considered in order to explore the possibility of adjusting engineering information to the needs of intervention teams (Figure 17). The survey conducted among firefighters has shown that the need for training exists, and that firefighters are interested in training relating to buildings and bridges, i.e. in learning local building typologies and in receiving practical training on supporting techniques for partially collapsed structures from which trapped people are to be rescued [82].
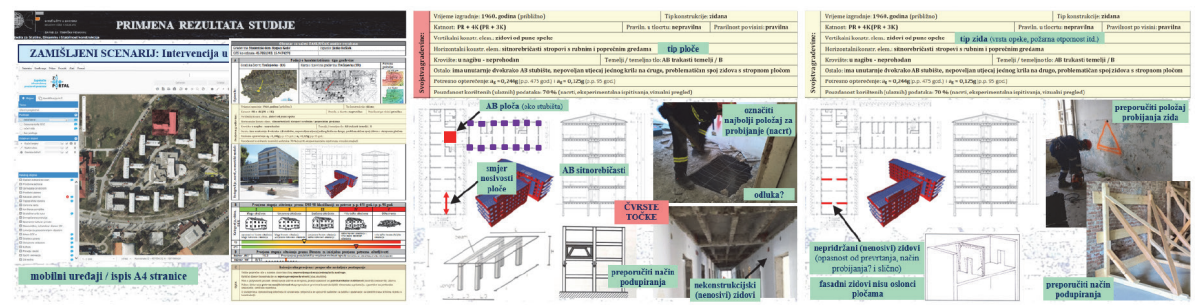

Figure I7. Hypothetical scenario for an intervention team exercise (in Croatian)

As a result of a successful long-term collaboration between the Faculty of Civil Engineering in Zagreb and the National Protection and Rescue Directorate, expert engineers from the faculty have joined Croatian urban search and rescue team (MUSAR) in the European civil protection exercise CASCADE' 19 held in Portugal in May 2019, which was funded by the EC under the EU Civil Protection Mechanism (Figure 16c). The aim of the exercise was to test and train the response to multiple emergencies that may occur in cascade (earthquake, floods, chemical accidents, dam collapse, marine pollution, etc.).

\section{Conclusions and recommendations}

The objective of this paper was to discuss the current state of knowledge and the various challenges related to the seismic risk and risk reduction efforts in Croatia. A particular emphasis was placed on the issues associated with seismic risk assessment, which represents the basis for development of efficient risk reduction strategies. It was demonstrated that, although the seismic risk in Croatia is high, the perception and awareness of the general public and decision makers about exposure and vulnerability to seismic threat is still very low. The fact that a strong earthquake would not only cause damage to built environment and people, but also result in the collapse of the country's economy while boosting one of the country's biggest problem, which is depopulation, is far from being generally accepted and recognised. Some efforts for seismic risk reduction, conducted by individual initiatives, are discussed, but these efforts do not suffice for building the required systematic risk reduction strategy at local and national levels. 
It is always preferable to learn and act based on the experience and reaction of countries that have already been devastated by strong earthquakes than to draw conclusions from our own negative experience. The efforts to increase seismic safety in Croatia should therefore involve continuous, systematic and comprehensive activities aimed at exploring different dimensions of the seismic risk reduction process. Potential activities focusing on seismic risk reduction and enhancement of community resilience, e.g. a more reliable seismic risk assessment, assessment of performance of individual critical and vulnerable structures, followed by development and application of appropriate risk mitigation (retrofitting) measures, are proposed in Figure 18.

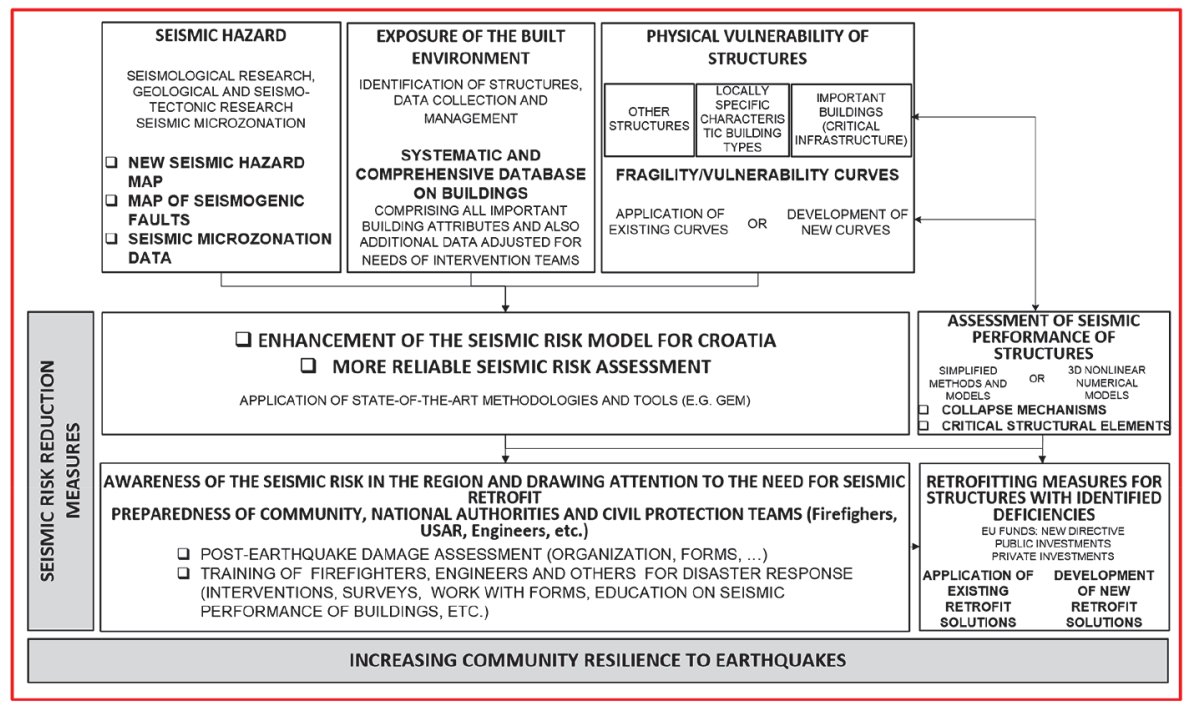

CROATIAN CENTRE FOR EARTHQUAKE RISK REDUCTION

Figure 18. Future trends for seismic safety in Croatia

\section{Generate knowledge}

The first essential step for strategic action is to solve the above challenges associated with seismic risk assessment, such as the lack of official databases on existing structures, seismic hazard issues, and development of locally specific fragility and vulnerability curves, described in detail in previous sections of the paper and in [83], [84], [86]. It is highlighted in this paper that it is crucial to invest in upgrading aged essential facilities and critical infrastructure (hospitals, schools, bridges, lifelines, etc.). The process with detailed seismic performance analyses, from which proposals can be generated for further risk reduction activities such as seismic retrofit, is also outlined. 


\section{Retrofit: combine and save}

Results generated through the risk assessment process should be used to increase the awareness of local communities of their own exposure and vulnerability to earthquakes, in order to encourage investment and implement measures such as retrofitting of existing buildings to improve their seismic resistance. This could be carried out during standard reconstructions/upgrading of buildings. Currently, the absence of investments in risk reduction measures is usually justified by the lack of funds, yet the main challenge is rather in the lack of awareness about seismic exposure and vulnerability.

The possibility to link the seismic retrofit programme to other activities financed by the EU has still not been utilized. An interesting opportunity to fill in the gap could be the renovation for energy efficiency, activities for which Croatia has already invested significant resources in the past several years in line with the EC recommendations. The cost-benefit analysis demonstrated that when energy and seismic retrofitting incentives are combined, the total cost is considerably lower than the costs when both retrofitting measures are applied independently [85]. In addition, the energy renovation applied individually significantly postpones potential seismic retrofit since it would require further construction interventions on the façades. In 2018, the Council of the EU issued a revised directive on energy performance of buildings (Directive 2018/844) which addresses the necessity of seismic retrofitting of buildings located in seismically active areas. It is expected that this directive will enhance enforcement of policies for investment in retrofitting of the most vulnerable structures, such as hospitals, schools, kindergartens, public institutions, and other critical infrastructure.

\section{Croatian centre for seismic risk reduction}

Comprehensive inventory databases, outputs of detailed seismic analyses (e.g., identified deficiencies), and knowledge and experience of engineers, can be linked together and then used for various activities, such as civil intervention teams activities. Currently, the efforts related to these issues are primarily made without significant financial resources, and they rely on the support of individual initiatives. Experience from countries that have already been devastated by earthquakes suggests that it is essential to link and coordinate activities of interested stakeholders (technical experts and scientists involved in the state-ofthe-art research in various fields important for seismic safety). This could only be achieved through a centre, such as the Croatian Platform for Disaster Risk Reduction, which would direct individual initiatives and act strategically in the long run in order to gradually reduce the earthquake risk, which must be our future trend. 


\section{Acknowledgements}

The authors gratefully acknowledge generous support by colleagues from the Department of Engineering Mechanics who contributed to various seismic studies that are partly presented in this paper. Thanks are especially extended to Damir Lazarević, Joško Krolo, Domagoj Damjanović, Ivan Duvnjak, Marko Bartolac, Janko Košćak and Zvonko Sigmund from the Construction Management Department. In addition, the support of colleagues from the University of Zagreb, Faculty of Science, Department of Geophysics and Sanja Hak from Bassler \& Hofmann, is greatly appreciated. Acknowledgements are also due to professor Dražen Aničić, who initiated seismic risk related studies in the City of Zagreb and whose comments on various challenges have proven to be extremely helpful. This work was partially supported by the City Office for Emergency Management, Ministry of Construction and Physical Planning, and by the Ministry of the Interior.

\section{Author's note}

This paper is based on the manuscript prepared for publication in journal Građevinar. Due to the importance of the topic covered, journal publication was for the purpose of this edition, extended and connected with the research performed at the Faculty of Civil Engineering.

\section{References}

[I] Atalić, J., Hak, S.: National disaster risk assessment in the Republic of Croatia - seismic risk (in Croatian), Faculty of Civil Engineering in collaboration with Ministry of Construction and Physical Planning and National Protection and Rescue Directorate, 2014.

[2] Giardini, D.,Woessner, J., Danciu, L.: European Seismic Hazard Map, Swiss Seismological Service, ETH Zürich, Switzerland (http://www.share-eu.org/), doi: 10.2777/30345, ISBN-I3, 978-92-79-25I48-I, 2013

[3] Herak M., Allegretti I., Herak D., Ivančić I., Kuk V., Marić K., Markušić S., Sović I.: Republic of Croatia, Seismic hazard map, 20I I. http://seizkarta.gfz.hr

[4] Markušić, S.: Seismicity of Croatia, E.S. Husbye (ed.): Earthquake Monitoring and Seismic Hazard Mitigation in Balkan Countries, Springer, pp. 8I-98, 2008. doi: I0.1007/978-I-4020-68I5-7

[5] Aničić., D., Mihaliov, V.,Velkov, M.: Restoration, seismic reconstruction and structural repair of cultural monuments in the old city centre of Dubrovnik (in Croatian), The Institute for Restoration of Dubrovnik, 1988.

[6] Simović,V.: Earthquakes in Zagreb area (in Croatian), Građevinar, 52 (2000) II, pp. 637-645

[7] Mlinarić, I.:Photos/video: 20 years since devastating earthquake in Ston (in Croatian), article published 5.9.2016. online, retrieved from http://dubrovniknet.hr/novost.php?id=479/5

[8] Markušić S., Herak D., Ivančić I., Sović I., Herak M., Prelogović E.: Seismicity in Croatia in the period 1993-1996 and the 1996 Ston Slano Earthquake of 1996, Geofizika I5 (I998), pp. 83-I02 
[9] Stojan, A., Crnogorac, M., Stiplašek, B., Čoro, D.: Structural repair of earthquake-damaged buildings in Ston and Dubrovnik littoral (in Croatian), Graditelji u razvitku Republike Hrvatske, HSGI, Cavtat, Croatia, pp. 105-II7, 2000.

[10] D'Ayala D.F., Paganoni, S.:Assessment and analysis of damage in L'Aquila historic city centre after 6th April 2009, Bulletin of Earthquake Engineering, 9 (20II) I, pp. 8I-I04, doi: I0.1007/s I05 I 8-0 I0-92244

[II] Penna, A., Morandi, P., Rota, M., Manzini, C. F., da Porto, F., Magenes, G.: Performance of masonry buildings during the Emilia 2012 earthquake, Bulletin of Earthquake Engineering, I2 (20I4) 5, pp. 2255-2273, doi: 10.1007/s 105 I8-013-9496-6

[12] Ricci, P., De Luca, F.,Verderame, G. M.: 6th April 2009 L'Aquila earthquake, Italy: reinforced concrete building performance, Bulletin of Earthquake Engineering, 9 (20II) I, pp. 285-305, doi: 10.1007/ sl0518-010-9204-8

[13] Rossi, A., Tertulliani, A., Azzaro, R. et al.: The 2016-2017 earthquake sequence in Central Italy: macroseismic survey and damage scenario through the EMS-98 intensity assessment, Bulletin of Earthquake Engineering, I7 (2019) 5, pp. 2407-243I, doi: I0.1007/s I05 I8-0I9-00556-w

[14] Maugeri M., Massimino M.R., Grasso S.: The 2012 Emilia-Romagna Earthquake (Italy): Lessons and Mitigation Measurements, The 18th International Conference on Soil Mechanics and Geotechnical Engineering, Paris, France, 2012.

[15] Aničić, D., Berz, G., Boore, D., Bouwkamp, J., Hakenbeck, U., McGuire, R., Sims, J., Wieczorek, G.: Reconnaissance Report: Montenegro,Yugoslavia Earthquake,April I5, 1979, Leeds,A. (Ed.), Matthiesen, R. B. (Coord.), Berkeley, Calif.: Earthquake Engineering Research Institute, USA, 1980.

[16] Sozen, M.A.: Structural damage caused by the Skopje Earthquake of I 963:a report to the Committee on Masonry and Reinforced Concrete of the American Society of Civil Engineers and the American Concrete Institute, Urbana, University of Illinois, USA, 1964.

[17] Ambraseys IZIIS: SKOPJE EARTHQUAKE of 26 July 1963 REVISITED, photographs

[18] Coburn A., Spence R.: Earthquake Protection, Second Edition, Wiley and Sons, 2002.

[19] Bal, I.E., Crowley, H., Pinho, R.: Displacement-Based Earthquake Loss Assessment: Method Development and Application to Turkish Building Stock, Research Report Rose 2010/02, IUSS Press, Pavia, Italy, 2010.

[20] Milutinović, Z.: Overview on systemic management of seismic risk in SFR Yugoslavia - experience and contribution of IZIIS, SERA Balkans Seismic Risk workshop, Belgrade, Serbia, 2019.

[2I] SFRY Official Gazette: Ordinance on Temporary Technical Regulations for Construction in Seismic Areas (in Croatian), SFRJ 39/64, 1964.

[22] SFRY Official Gazette, Code of Technical regulations for the construction of building in seismic areas (in Croatian), SFRJ 3I/8I, 49/82, 29/83, 20/88, 52/90

[23] United Nations Industrial Development Organization: Building Construction under Seismic Conditions in the Balkan Region, Terminal report, DP/RER/79/0I5/H/0I/37,Vienna, 1986.

[24] World Bank, https://datahelpdesk.worldbank.org/knowledgebase/articles/9065I9-world-bankcountry-and-lending-groups, I.7.2019.

[25] Calvi, G.M., Pinho, R., Magenes, G., Bommer,J.J, Restrepo-Vélez, L.F. and Crowley, H.: Development of Seismic Vulnerability Assessment Methodologies Over the Past 30 Years, ISET Journal of Earthquake Technology, 43 (2006) 3, pp. 75-I04., doi: I0. I007/s I I069-0I I-0082-4 
[26] Ivančić, I., Herak, D., Herak, M.,Allegretti, I., Fiket,T., Kuk, K., Markušić, S., Prevolnik, S., Sović, I., Dasović, I., Stipčević, J.: Seismicity of Croatia in the period 2006-2015, Geofizika, 35 (2018) I, pp. 69-98, doi: I0.15233/gzz.2018.35.2

[27] Herak, M., Herak, D., Markušić, S.: Revision of the earthquake catalogue and seismicity of Croatia, 1908-1992,Terra Nova, 8 (1996), pp. 86-94., doi: 10.1 II I/j.1365-3 I21.1996.tb00728.x

[28] Map of earthquake epicentres in Croatia, https://www.pmf.unizg.hr/geof/seizmoloska_sluzba/o_ seizmologiji

[29] Herak, D., Herak, M.,Tomljenović, B.: Seismicity and earthquake focal mechanisms in North-Western Croatia, Tectonophysics, 465 (2009), pp. 2I 2-220., doi: 10. I0I6/j.tecto.2008.12.005

[30] Kuk,V., Prelogović, E., Sović, I., Kuk, K., Šariri, K.: Seismological and seismo-tectonical properties of the wider Zagreb area (in Croatian), Građevinar, 52 (2000) II, pp. 647-653

[3I] HZN:HRN EN 1998-I:20II+/Ispr.2:20I5+AI:20I4+NA:20II, Eurocode 8: Design of structures for earthquake resistance - Part I: General rules, seismic actions and rules for buildings (in Croatian), Zagreb, Croatia, 20II.

[32] Markušić, S., Gülerce, Z., Kuka, N., Duni, L., Ivančić, I., Radovanović, S., Glavatović, B., Milutinović, Z., Akkar, S., Kovačević, S., Mihaljević, Ja., :Šalić, R.: An updated and unified earthquake catalogue for the Western Balkan Region, Bulletin of Earthquake Engineering, 14 (2016) 2, pp. 32I-343, doi: 10.1007/ sl0518-015-9833-z

[33] Spence, R., Foulser-Piggott, R., Pomonis, A., Crowley, H., Masi, A., Chiauzzi, L., Zuccaro, G., Cacace, F., Zulfikar, C., Markus, M., Schaefer, D., Sousa, M.L., Kappos, A.:The European Building Stock Inventory: Creating and Validating a Uniform Database for Earthquake Risk Modelling, Proceedings of the 15th World Conference of Earthquake Engineering, Lisbon, Portugal, 2012.

[34] Croatian Bureau of Statistics (20II): Census 20II, Occupied dwellings by period of construction, type of building and number of households in dwelling, www.dzs.hr

[35] Crowley, H., Ozcebe, S., Spence, R., Foulset-Piggott, R., Erdik, M.,Alten, K.: Development of a European building inventory database, Proceedings of 12th World Conference on Earthquake Engineering, Lisbon, Portugal, 2012.

[36] Crowley, H.: Earthquake Risk Assessment: Present Shortcomings and Future Directions, in Ansal, A. (ed.) Perspectives on European Earthquake Engineering and Seismology, Geotechnical, Geological and Earthquake Engineering 34, Springer, New York., 2014.

[37] Crowley, H., Ozcebe, S., Baker, H., Foulser-Piggott, R., Spence, R.: D7.2 State of the Knowledge of Building Inventory Data in Europe, NERA - Seventh Framework Programme EC project number: 262330 www.nera-eu.org, 2014.

[38] Gamba, P., Cavalca, D. Jaiswal, K., Huyck, C., Crowley, H.: The GED4GEM Project: Development Of a Global Exposure Database for the Global Earthquake Model Initiative, Proceedings of the 15th World Conference on Earthquake Engineering, Lisbon, Portugal, 2012.

[39] Gamba, P.: Global Exposure Database: Scientific Features, GEM Technical Report 20I4--IOVI.0.0, 46Pp., GEM Foundation, Pavia, Italy, 20I4. doi: I0.131 I7/GEM.EXP--MOD.TR2014.10

[40] Pinho, R.: GEM:a participatory framework for open, state-of-the-art models and tools for earthquake risk assessment, Proceedings of the 15th World Conference of Earthquake Engineering, Lisbon, Portugal, 2012.

[4I] Brzev S., C. Scawthorn,A.W. Charleson, L.Allen, M. Greene, K. Jaiswal,V. Silva: GEM Building Taxonomy Version 2.0, GEM technical report 2013-02 VI.0, GEM Foundation, Pavia, Italy, 2013.

[42] Atalić, ].: Exposure model in Croatia, SERA European Exposure Workshop, Pavia, Italy, 2018. 
[43] Atalić, J., Šavor Novak, M., Uroš, M.: Development of exposure model for Croatia, SERA Balkans Seismic Risk workshop, Belgrade, Serbia, 2019.

[44] Šavor Novak, M., Uroš, M., Atalić, J.: Challenges associated with seismic risk assessment in Croatia, SERA Balkans Seismic Risk workshop, Belgrade, Serbia, 2019.

[45] Hadzima-Nyarko, M.: Creating the database of buildings of Osijek, Croatia, research performed at the Faculty of Civil Engineering and Architecture Osijek, SERA Balkans Seismic Risk workshop, Belgrade, Serbia, 2019.

[46] Atalić, J., Šavor Novak, M., Uroš, M.: Updated risk assessment of natural disasters in Republic of Croatia - seismic risk assessment (in Croatian), Faculty of Civil Engineering in collaboration with Ministry of Construction and Physical Planning and National Protection and Rescue Directorate, 2018.

[47] Atalić, J., Krolo, J., Damjanović, D., Uroš, M., Sigmund, Z., Šavor Novak, M., Hak, S., Korlaet, L., Košćak, J., Duvnjak, I., Bartolac, M., Serdar, M., Dokoza, I., Prekupec, F., Oreb, J., Mušterić, B.: Study on earthquake risk reduction in the City of Zagreb, Phase I-6 (in Croatian), Faculty of Civil Engineering, Department of Engineering Mechanics, 2013-20I8.

[48] Pitilakis, K., Crowley, H., Kaynia,A.M. (Eds.):SYNER-G:Typology Definition and Fragility Functions for Physical Elements at Seismic Risk: Buildings, Lifelines, Transportation Networks and Critical Facilities, Geotechnical, Geological and Earthquake Engineering, Springer, 27, Springer Science+Business Media Dordrecht, 2014. doi: 10.1007/978-94-007-7872-6

[49] Kircher, C.A., Nassar, A.A., Kustu, O., Holmes W.T.: Development of Building Damage Functions for Earthquake Loss Estimation, Earthquake Spectra, I 3 (I997) 4, pp. 663-682. doi: I0. I I93/I.I585974

[50] Silva, V.: Development of open-source tools for seismic risk assessment: application to Portugal, PhD Thesis, University of Aveiro, Portugal, 2013.

[5I] Hadzima-Nyarko, M., Nikić, D., Morić, D.: Earthquake engineering - Vulnerability assessment of buildings (in Croatian), University J.J. Strossmayer in Osijek, Faculty of Civil Engineering Osijek, Croatia, 2018.

[52] D’Ayala, D., Meslem, A., Vamvatsikos, D., Porter, K., Rossetto, T., Silva, V.: Guidelines for Analytical Vulnerability Assessment of Low/Mid-Rise Buildings, Methodology, Vulnerability Global Component project, 20I5., doi: I0.131 I7/GEM.VULN-MOD.TR20I4.12

[53] Bal, I.E., Gülay, F.G., Tezcan, S.S.: A New Approach for the Preliminary Seismic Assessment of RC Buildings: P25 Scoring Method, Proceedings of the 14th World Conference on Earthquake Engineering, Beijing, China, 2008.

[54] Maio, R., Tsionis, G., Sousa, M.L., Dimova, S.: Review of fragility curves for seismic risk assessment of buildings in Europe, I6th World Conference on Earthquake, I6WCEE 20I7, Santiago Chile, Paper $N^{\circ}$ $3283,2017$.

[55] Pejovic, J., Jankovic, S.: Seismic fragility assessment for reinforced concrete high-rise buildings in Southern Euro-Mediterranean zone, Bulletin of Earthquake Engineering, 14 (2016) I, Pp. I85-2I2., doi: $10.1007 / \mathrm{s} 10518-015-9812-4$

[56] Silva,V., Crowley, H., Pinho, R., Varum, H.: Extending displacement-based earthquake loss assessment (DBELA) for the computation of fragility curves, Engineering Structures, 56 (2013), pp. 343-356, doi: 10.1016/j.engstruct.2013.04.023

[57] Silva, V., Crowley, H., Varum, H., Pinho, R.: Evaluation of analytical methodologies used to derive vulnerability functions, Earthquake Engineering \& Structural Dynamics, 43 (20I4) 2, pp. I8I-204., doi: 10.1002/eqe.2337 
[58] Silva, V., Crowley, H., Varum, H., Pinho, R.: Seismic risk assessment for mainland Portugal, Bulletin of Earthquake Engineering, 13 (20I5) 2, pp. 429-457, doi: 10.1007/s I05I8-0I4-9630-0

[59] Rota, M., Penna, A., Magenes, G.: A methodology for deriving analytical fragility curves for masonry buildings based on stochastic nonlinear analyses, Engineering Structures, 32 (2010), pp. 13/2-1323, doi: $10.1016 / j$.engstruct.2010.01.009

[60] Rossetto, T., Elnashai, A.: A New Analytical Procedure for the Derivation of Displacement-Based Vulnerability Curves for Populations of RC Structures, Engineering Structures, 7 (2005) 3, pp. 397 409, doi: 10.1016/j.engstruct.2004.II.002

[61] Milutinovic, Z., Trendafilovski, G.: An advanced approach to earthquake risk scenarios with applications to different European towns - WP4:Vulnerability of current buildings, RISK-EU, 2003.

[62] Grünthal, G.: European Macroseismic Scale, Cahiers du Centre Européen de Géodynamique et de Séismologie, 15, 1998.

[63] Giovinazzi, S., Lagomarsino, S.: A Macroseismic Model for the vulnerability assessment of buildings, 13th World Conference on Earthquake Engineering,Vancouver, Canada, No. 896, 2004.

[64] Lagomarsino, S., Giovinazzi, S.: Macroseismic and mechanical models for the vulnerability and damage assessment of current buildings, Bulletin of Earthquake Engineering, 4 (2006) 4, pp. 4I5-443, doi: |0.1007/s |05|8-006-9024-z

[65] Šavor Novak, M., Atalić, J., Damjanović, D., Uroš, M., Krolo, J., Sigmund, Z., Košćak, J., Korlaet, L., Bartolac, M., Duvnjak, I. Hak, S.: Study on Seismic Risk Mitigation in the City of Zagreb, Croatia, Proceedings of the VII Conference of Croatian platform for disaster risk reduction, NRPD (Ed.), Zagreb, Croatia, pp. I27-134, 2018.

[66] Uroš, M., Šavor Novak, M.,Atalić, J., Prevolnik, S.: Seismic performance assessment of existing buildings (in Croatian), Mini-Symposium on Numerical Methods, Faculty of Civil Engineering, Zagreb, Croatia, Pp. 173-187, 2019. doi: 10.5592/CO/YODA.2019.4.4

[67] Hadzima-Nyarko, M., Lešić, M., Morić, D.: Seismic Vulnerability Assessment for Residential Buildings in Osijek, Croatia, Proceedings of the 16th World Conference on Earthquake Engineering, Chilean Association of Seismology and Earthquake Engineering Board Directors ACHISINA, Santiago, 2017.

[68] Hadzima-Nyarko, M., Ademović, N., Pavić, G.: Assessment of Seismic Vulnerability of old Masonry Buildings using Analytical Method (in Croatian), Proceedings of the 6th international conference Earthquake Engineering and Engineering Seismology, Kraljevo, Serbia, pp. 317-324, 2018.

[69] Hadzima-Nyarko, M., Kalman Šipoš, T.: Insights from existing earthquake loss assessment research in Croatia, Earthquakes and Structures, I3 (2017) 4, pp. 40 I-4II, 2017 doi: I0.12989/eas.20I8. I3.4.365

[70] Prevolnik, S., Mustać, M., Herak, M., Alegretti, I., Dasović, I., Fiket, T., Ivančić, I., Kuk, K., Markušić, S., Sović, I., Stipčević, J., Štih, D., Atalić, J.,Šavor Novak, M.: Instrumental measurements of SPBs in the Dubrovnik-Neretva County, University of Zagreb, Faculty of Science, Department of Geophysics and University of Zagreb, Faculty of Civil Engineering, Department of Engineering Mechanics, Interreg Readiness, Italy-Croatia, European Regional Development Fund, EU, 2019.

[7I] Prevolnik, S., Herak, M., Dasović, I., Fiket, T., Ivančić, I., Kuk, K., Markušić, S., Mustać, M., Sović, I., Stipčević, J., Štih, D., Uroš, M., Atalić, J.Šavor Novak, M., Lazarević, D., Damjanović, D., Bartolac, M.: Seismic performance assessment of Building D of General Hospital Dubrovnik, University of Zagreb, Faculty of Science, Department of Geophysics and University of Zagreb, Faculty of Civil Engineering, Department of Engineering Mechanics, Interreg Readiness, Italy-Croatia, European Regional Development Fund, EU, 2019. 
[72] Petal, M.: Earthquake Casualties Research and Public Education (Chapter), Human Casualties in Earthquakes. Advances in Natural and Technological Hazards Research, eds. R. Spence, E. So \& C. Scawthorn, Springer, Dordrecht, pp. 25-50, 201 I.

[73] Silva, V., Amo-Oduro, D., Calderon, A., Dabbeek, J., Despotaki, V., Martins, L., Rao, A., Simionato, M., Viganò, D., Yepes-Estrada, C., Acevedo, A., Crowley, H., Horspool, N., Jaiswal, K., Journeay, M., Pittore, M.: Global Earthquake Model (GEM) Seismic Risk Map (version 2018.I), doi: 10.131I7/GEMGLOBAL-SEISMIC-RISK-MAP- 2018., 2018.

[74] National Protection and Rescue Directorate (DUZS), Republic of Croatia: Ordinance on the methodology of development of vulnerability assessments and plans of protection and rescue (in Croatian), NN 38/08 and I I 8/I2, 2008.

[75] National Protection and Rescue Directorate (DUZS), Republic of Croatia: Ordinance on guidelines for development of natural disasters and large accidents for the area of Republic of Croatia and local and regional administrative units (in Croatian), NN 65/16, 2016.

[76] Jurak, V., Ortolan, Ž., Ivšić, T., Herak, M., Šumanovac, F., Vukelić, I., Jukić, M., Šurina, Z.: Geotechnical and seismic microzonation of Zagreb - attempts and realization (in Croatian), Konferencija: Razvitak Zagreba, Zagreb, 2008.

[77] Herak, M., Allegretti, I., Dasović, I., Fiket, T., Herak, D., Ivančić, I., Kuk, K., Kuk, V., Marić, K., Markušić, S., Prevolnik, S., Sović, I., Stipčević, J.: Seismic and geological microzonation of western part of urban area under Medvednica Mountain according to Eurocode 8 standards, testing results (in Croatian), Faculty of Science, Department of Geophysics, 2013.

[78] Akkar S., Boomer, J.J.: Empirical equations for the prediction of PGA, PGV, and spectral accelerations in Europe, the Mediterranean region, and the Middle East, Seismological Research Letters, $8 \mathrm{I}$ (20I0) 2, pp. 195-206 doi: 10.1785/gssrl.81.2.195

[79] QGIS Development Team: QGIS Geographic Information System, Open Source Geospatial Foundation Project, 2019. http://qgis.osgeo.org

[80] Government of Republic of Croatia: National disaster risk assessment in Republic of Croatia (in Croatian), http://www.platforma.hr/images/dokumenti/Procjena_rizika_RH_svi_FINAL.pdf, 2015.

[8I] Atalić, J., Sigmund, Z., Šavor Novak, M., Uroš, M., Damjanović, D., Duvnjak, I., Košćak, J., Dokoza, I., Reich, S., Prekupec, F.: Role of civil engineering experts in situations after devastating earthquakes (in Croatian), Proceedings of the VII Conference of Croatian platform for disaster risk reduction, NRPD (Ed.), Zagreb, Croatia, pp. I35-I43, 2018.

[82] Atalić, J., Šavor Novak, M., Uroš, M., Hak, S., Damjanović, D., Sigmund, Z.: Measures for the earthquake risk reduction in the city of Zagreb, Croatia, 16th European Conference on Earthquake Engineering, Thessaloniki, Greece, 2018.

[83] Atalić, J., Šavor Novak, M., Uroš, M., Hak, S.: Challenges of the seismic risk assessment in Croatia (in Croatian), Proceedings of the 6th international conference Earthquake Engineering and Engineering Seismology, Kraljevo, Serbia, pp. 65-80, 2018.

[84] Atalić, J., Šavor Novak, M., Uroš, M., Hak, S.: Problems in the seismic risk assessment in Croatia (in Croatian), Proceedings of the VII Conference of Croatian platform for disaster risk reduction, NRPD (Ed.), Zagreb, Croatia, pp. I08-I16, 2018.

[85] Mastroberti, M., Bournas, D., Vona, M., Manganelli, B., Palermo, V.: Combined seismic plus energy retrofitting for the existing $\mathrm{RC}$ buildings: economic feasibility, $16^{\text {th }}$ European Conference on Earthquake Engineering, Thessaloniki, Greece, 2018.

[86] Atalić, J., Šavor Novak, M., Uroš, M.: Seismic risk for Croatia: overview of research activities and present assessments with guidelines for the future, GRAĐEVINAR, 7I (20I9) 10 